AKADEMIE DER WISSENSCHAFTEN DER DDR

Forschungsbereich Geo- und Kosmoswissenschaften ZENTRALINSTITUT FUR PHYSIK DER ERDE

Veröffentlichungen des Zentralinstituts für Physik der Erde Nr. 46

\title{
Rift Activity in the Eastern Pacific
}

by

Elfriede Bankwitz

Peter Bankwitz

Als Manuskript gedruckt

Potsdam 1978 


\section{Contents}

1. Introduction

2. Superordinate rotations of the East Pacific Rift between $20^{\circ}$ and $60^{\circ} \mathrm{N}$.

2.1. The clockwise rotation of the $\mathbb{N}_{\bullet} \mathrm{E}_{\text {. Pacific Rift }} 80 \mathrm{~m} \cdot \mathrm{J} \cdot \mathrm{b} \cdot \mathrm{p}_{\text {. }}$ (1st period)

2.2. The counterclockwise rotation of the $N_{0} E_{\text {. Pacific Rift }}$ from 71 to $63 \mathrm{~m} \cdot \mathrm{J} \cdot \mathrm{b} \cdot \mathrm{p}$. (2nd period)

2.3. Rotations of the rift during a transitional stage about 65 to $60 \mathrm{~m} \cdot \mathrm{y} \cdot \mathrm{b} \cdot \mathrm{p} \cdot(3 \mathrm{rd}$ period)

2.4. The great clockwise rotation of the N.E. Pacific Rift 63 to $50 \mathrm{~m} \cdot \mathrm{J} \cdot \mathrm{b} \cdot \mathrm{p} \cdot(4 \mathrm{th}$ period)

2.5. Rotations with a stabilizing function in a transitional stage from 50 to $40 \mathrm{~m} \cdot \mathrm{J} \cdot \mathrm{b} \cdot \mathrm{p}$. (5th period)

2.6. The great counterclockwise rotation of the N.E. Pacific Rift 43 to $20 \mathrm{~m} \cdot \mathrm{y} \cdot \mathrm{b} \cdot \mathrm{p}_{\text {. }}$ (6th period)

3. Total rotation of the East Pacific Rift between Clarion and Aja Fracture Zones

3.1. Sum of rotations of the rift

3.2. Special position of the plate section between $33^{\circ}$ and $37^{\circ} \mathbb{N} . \quad 25$

3.3. The significance of the Mendocino-Pioneer double structure 25

4. Rotations of the Pacific-Antarctic Rift between $30^{\circ}$ and $65^{\circ} \mathrm{S} .28$

4.1. Complex movements of the rift 28

4.2. Recent tendencies 30

5. Magmatic activity of the sift 31

5.1. Characteristics of rift activity 31

5.2. Hinge zones of the rift rotations 34

6. Plate deformation 40

6.1. Rift rotation at a collision of plates 40

6.2. Rift shortening due to compression 40

7. Conclusions 4.4

$\begin{array}{ll}\text { References } & 45\end{array}$ 
S u nin m $\mathrm{m}$ 工 $y$

The permanent rotation of the $N_{6}$ E.Pacific Rift is divided into three firstmorder rotations covering the whole rift between $20^{\circ}$ and $60^{\circ} \mathrm{N}$. during the last 80 mio jears. The general movement of a clockwise rotation ( $35-40^{\circ}$ altogether) was interrupted durm ing the time between 40 and $20 \mathrm{~m} \cdot \mathrm{J} \cdot \mathrm{b} . \mathrm{p}$. by a weal counterciockwise one $\left(8^{\circ}\right.$ altogether). These superordinate rotations can be subdivided in smalier ones with an average duraw tion of $10 \mathrm{~m} \cdot \mathrm{y}$ only. It is to suppose that all these rotations are a readjustment of the rift to a changed position of the spreading pole. Comoared to it, shortstime, oscillatory rotations represent compensating movements of the rift and stabilizing efforts of the plate. For the S.E.Pacific Rift it is supposed that the counterclockwise rotation taking place there for the last $7 \mathrm{m.J}$. is continuing, as may be concluded from the distribution of earthquake epicentres.

Burthemore, the problems of pendulum movements and hinge zones at the $S_{\text {. }} E_{\text {. }}$ and N. Eacific Rifts are discussed, which represent the magratic activity of the rift. Hinge zones are lines of weakness of rifts, which can become favit zones. Up to now they were not mentioned in literature.

The internal defornations of the Pacific Plate and Juan de Fuca Plate off California indicated by kinks of the rift, faultalolding and strike slip faults became

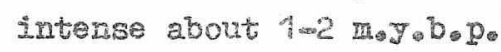

2 นะ อ

Die permanente Rotation des NE-Pazifiøchen Rifts wähend der letzten 80 Mill. JahTe igt in drei Etappen 1.Ordnung zu untertelien, von denen der geamte Rift zwischen $20^{\circ}$ und $60^{\circ} \mathrm{n}$. Br. exfaBt wurde. Die generelle Rechtsrotetion des Rifta um 1nggesamt $35^{\circ}=40^{\circ}$ wurde vor 40 H11. Jehren fur einen Zeitraum von 20 H111. Jabren unterbrochen durch eine schwache Inkgrotation des geamten Rifta um maximal $8^{\circ}$. Diege ủbergeordneten Rotationen tberlagem Drehungen des Rifts, die durchschnittich nur 10 MIII. Jahre andauern. Beide ergeben aich offenbar aus der Reorfentierung dea Rifts vährend oder aach einer Verlagerung des Spreadingpola. Dagegen vertreten kurazeitige, oszillator. ache Rotationen Augleichsbewegungen des Rifta, die offenbar der Stgbilisierung dex Platte dienen. Die Vexteilung der Erdbebenzentren am SE-Pazifischen RIft deutet darauf hin, dab die Iinksrotation dex letzten 7 fifill. Jahre noch enhält.

Pendelbewegungen einzelner RIPtabschnitte an Storungen und Scharaierilnien gplegeln die magnatische Aktivität dea Rifta wider. Bei den Schamlezinien handelt es gich un Schwëchezonen der Rifte, die aich zu Bruchzonen entwickeIn koinnon. Sie aind bisher in der Iiteratur nicht bekannt geweren.

Die platteninteme Deformation der Parifichen und der Juan-de-Fuce-PIatte vor der Kuste Califomiens setzte Intensiv vor $1-2$ Mil. Jahres ein. 
Постоянное вращение риф̆та северо-восточной части Тихого океана во время последных 80 милл. лет подразделяется в три этапа I порядка, которые охватывали весь рифт от $20^{\circ}$ до $60^{\circ}$ с.п. Общее левое вращение рифта на всего $35^{\circ}-40^{\circ}$ прервано незначительным левым вращением всего риста 40 милл。 лет тому назад длительностьл 20 милл. лет на максимально $8^{\circ}$. Вращения I порядка накладывают вращения, продолжающиеся лишь I0 милл。 лет. Оба двитения, очевидно, вытекают из реориентации рифта до илг после перемещения полюса спрединга. По сравнению с этим краткосрочные осцилляционные вращения представляют собой компенсирующие движения, способствующи, по-видимому, стабилизацию плиты. Распределение центров землетрясений риф̆та юго-западной части Тихого океана указывает на еще действующее левое вращение последных 7 милл。 лет.

Колебательные двинения опредеденных отрезков рифта по.разломам и шарнирным линиям отражают магматическуо активность рифота。 Шарнирные линиц представляют собой зоны ослабления рифта, из которых могут образоваться зоны разломов. В литературе они до сих пор не описывались.

Интенсивные деф̆ормациц внутри плиты Тихого океана и плиты Хуан де фуга, находящихся под беретом Калифорнии, начали I - 2 милл. лет тому назад. 
1. Introduction

The present peper deals with some geologicel processes taking place at rifts in the oceanlecrut. They are by no means speciflc only to the Pacific Rift (FIg. 1), but the latter is the object of investigation, because detalled recorda of magnetic anomaliea heve been published for a large a coherent ares that they could be used a. inftial data for our conasderations.

An attempt 1 made to show the way in which the magatide activity of the rift causer and influences tectonlc procesees. Magmatlsm forms the mein parts of the ocean floor exd, in the form of stripes having different agea, 1te gpetial rhythm, producIng the formation and activation of fauts and Practure zones, that is to say, it stamps the development of ective rifts. The rift nust resct on charges of pole positiong, on the influence of other plates, and this in a variety of forme specifle to the rift. On the other hand, it preaents characteristica of ectivity (equidiatence, behaviour of magnatic centres and fracture zones) to be found in the continental crust as we11.

Flually, we are aeking general characteriatics of tectonic movements, with the interpretetion of magnetic anomelies as method and the demonstretion of block end rift rotetione (the mein avbject of the paper) only as a means to an end. From the investigations realts that, presumably for all processes to be described in this papex, regularties (to which no importance has been attached ao lar 1n part) seem

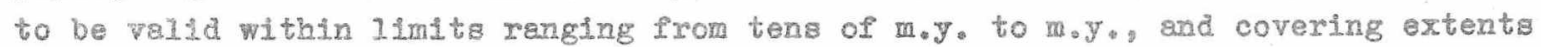
from more than $1,000 \mathrm{~km}$ to $10 \mathrm{~km}$. Just the differences from the general behaviour have excited our attention and, finally, mede vialble phenomena and relotiona chsrectering real geological processea taking place in a well-ordered manner.

Although the aspect of rift tectonies, by the detailed processes of novements to be demonstrated (rift and block rotation, rift deformation, development stages of frecture zones), becomer more intricate, 1ta apperance to a certain degree also becomeg more geologicel in that line pattems in the form of magnetic anomelies do not move from the rifta acrose the ocean 1loor, but thet geological bodies are on the move, living an latricate tectoulc "life of their own, even at a relatively eimple geometry.

For our investlgations we used magnetic anomalies published by ATWATHR (1970), HEIRTZLER et.21. (1966), HERRON (1971, 1972) and NAUGIHR \& WAGHMAN (1973). 


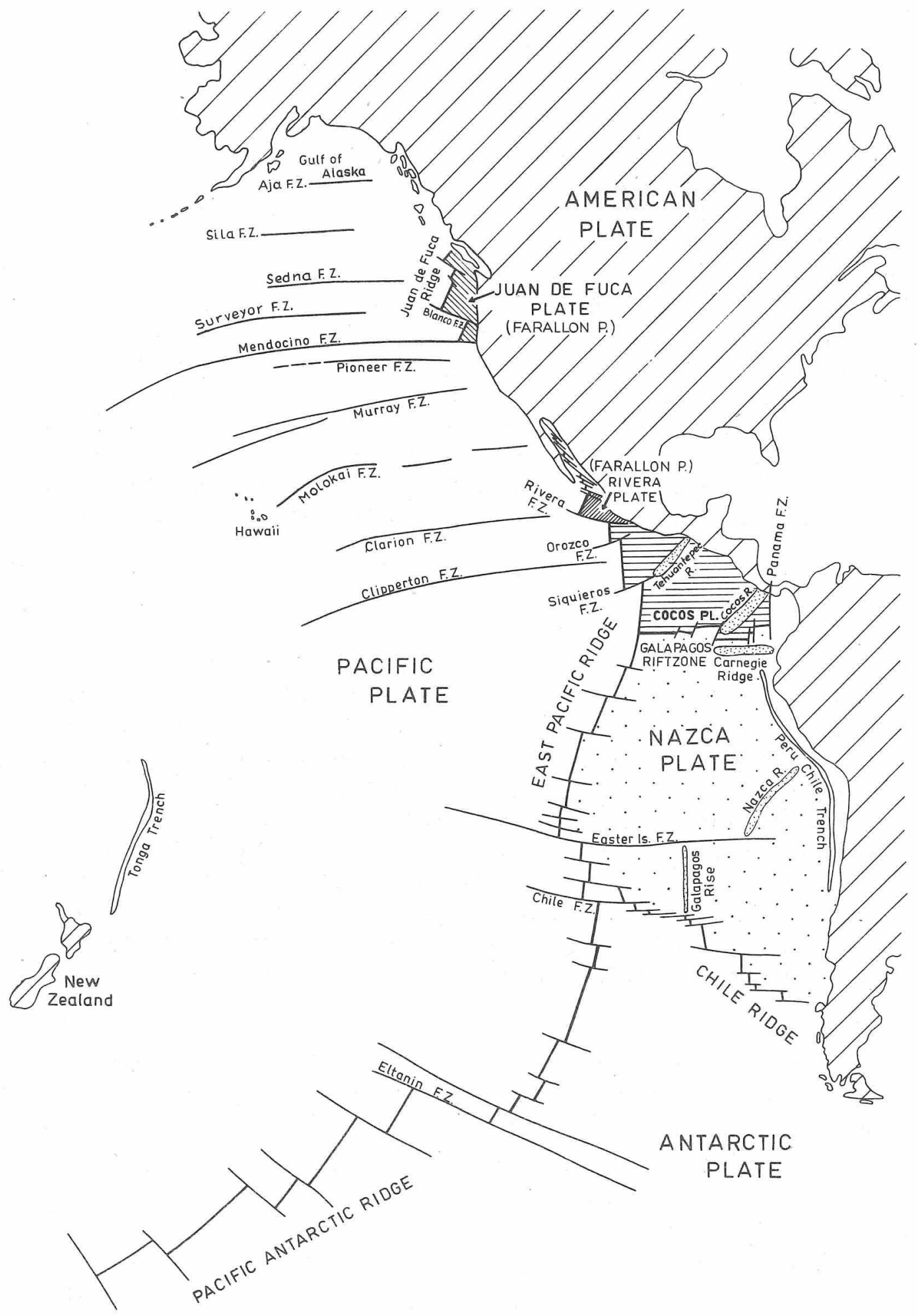

Fig. 1. Sketch map of the tectonic structures in the Fastern Pacific. Sources: ATWATER 1970, STOVER 1973, GIERLOFF-EMDEN 1970 
2. Superordinate rotations of the East Pacific Rift between $20^{\circ}$ and $60^{\circ} \mathrm{N}$.

The following considerations refer to the N.E. Pacific in the area between $20^{\circ}$ and $60^{\circ}$ N. as yell as $105^{\circ}$ and $170^{\circ}$ W. (between the Clarion Fracture Zone and the coast of Alasks, Fig. 2). Humerous studies published on the tectonic development of the Paciflc Plate are not to be diacussed here. Rather the change of position undergone by individual magnetic anomalies is considered and compared with older adjoining anomalies, from which conclusiong are drawn on rotatlons of the rift in the meantime. By VOGT ot al. (1969) the posalble mechaniom for rift rotations is seen in the magma tic material injected obliquely within the main injection zones of the rift. The schematic representation given by these author in F1B. 10B, p. 294, can be completed and raried by our observations of the anomalies between $52^{\circ}$ and $56^{\circ}$ No (between the Sila and Aje Fracture Zones). In Fig. 14 the possible stages of rift sections rotating step by step are represented in the row $A$ and $B, 1,0 .$, in $a$ way aB thoy might have preceded the changing positions and shapes of the anomalies 15 to 6 , when we regard it as a premise that the position, shapes and width of the anomalles are generally a result of the magmatic activity at the rift, and are directly connected one with another,

2.1. The clockwase rotation of the N.E. Pacific Rift $80 \mathrm{~m} \cdot \mathrm{F}_{0} \mathrm{~b} \cdot \mathrm{P}$. (1 gt period)

The first clockwise rotstion of the N.R. Pacific Rift which is demonstrated by numbered anomalies began north of the Surveyor Fracture Zone (F.t.) with anomaly 32 A (80 milifon years ago) at (today) $42^{\circ} \mathrm{N}$. South of this zone the clockwire rotge tion did not begin until it had diminished north of it, at the time of anomaly 31

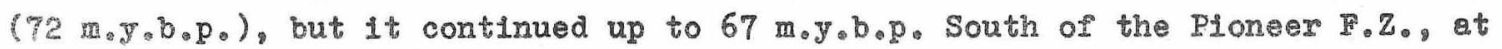
$37^{\circ} \mathrm{H}$, the rift even rotated up to $65 \mathrm{~m} \mathrm{y}_{\circ} \mathrm{b}_{\circ} \mathrm{p}_{0}$, thet is, by 2 m.y. Purther. Fig. 3 shows achematically the beginning of this rotition in the individual rift gections betweon $20^{\circ}$ and $55^{\circ} \mathrm{N}$. (fault displacements are eliminated, numbers represont the corresponding anomalies), according to the sepresentation of anomalies (Fig. 2 ). The width of anomalies was represented uniformly to compare directly between synchronous anomalies.

By this representation the rotations of the individual rift sections can be reduced to three group (I, II, III) in which the rotation had proceeded from north to south. That means, about $80 \mathrm{~m} . \mathrm{y}$. ago the rotation nearly began at the same time:

north of the Surveyor F. $\mathrm{Z}_{\text {. }}\left(46^{\circ} \mathrm{N},\right)_{\text {, }}$ south of the Mendociao F.Z. $\left(39^{\circ} \mathrm{N}.\right)$, south of the Molokal F. $\mathrm{F}_{0}\left(22^{\circ} \mathrm{N} \cdot\right)$,

and continued there more than 10 to $15 \mathrm{~m} . \mathrm{J}$. for a differently long time. Within 6 to $8 \mathrm{~m}, \mathrm{y}$. next after the beginning, the rift rotation proceeded towards the south, and with a maximum delay of $9 \mathrm{~m} . \mathrm{y}$. attained the southern end of the blocks I and II, that means, the sections north of the Mendocino F.Z. and north of the Moloka1 F, Z. Thus, $9 \mathrm{~m} \cdot \mathrm{y}$. after the beginning of these coinciding rift movements the whole East Paciflc Rift, between $20^{\circ}$ and $47^{\circ} \mathrm{N}$. roteted in clockwire direction. 


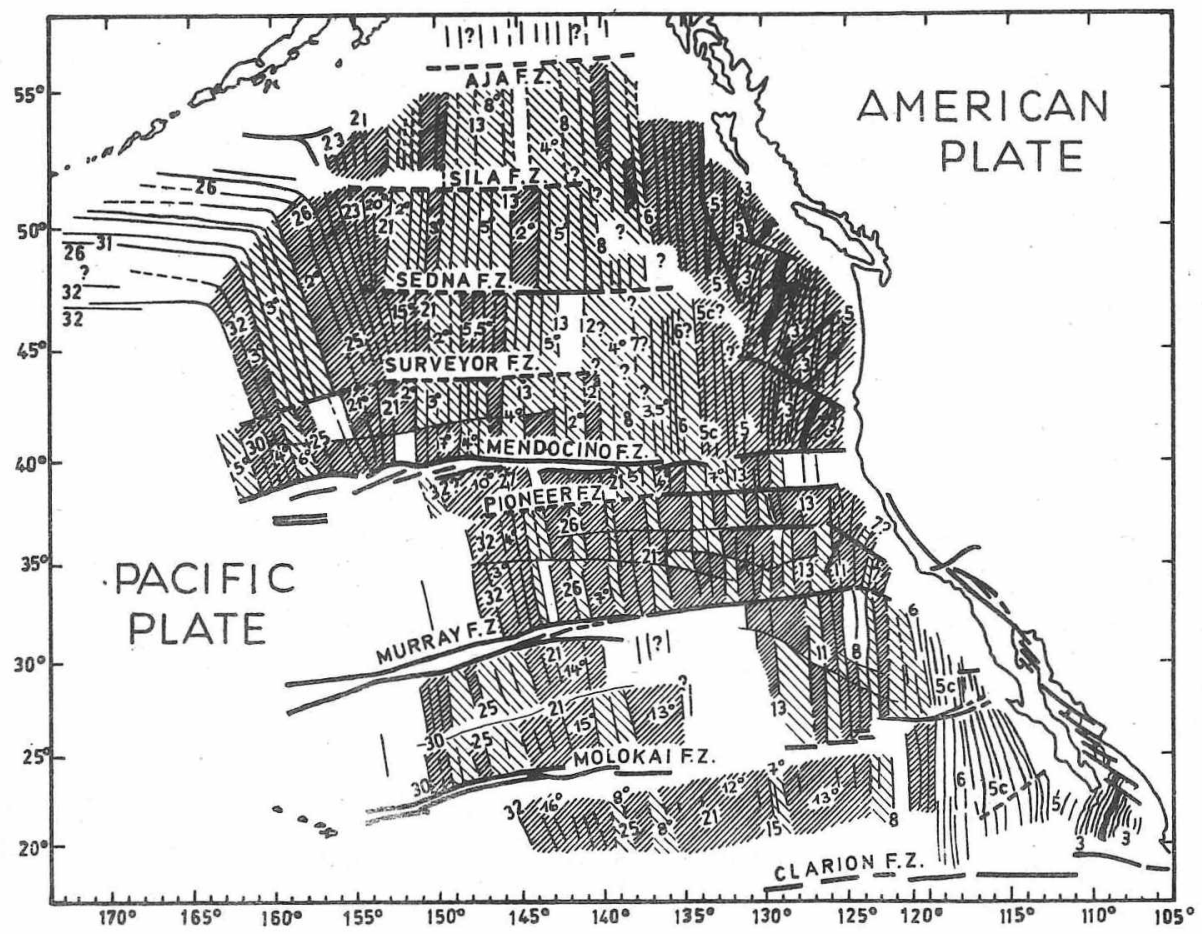

Fig. 2. Rotationg of the East Pacific Rift. Anomalies after ATWATER \& MENARD 1970. Clockwise and counterclockwise rotation: hatches inclined to the right and to the left. Additional faults or hinge lines, resp., between Surveyor and Molokai F.Z.s: fine lines. Numerals: numbers of anomalies; degrees: rotation rates of uniformly hatched areas. Black stripes off North America: East Pacific Rift 
The ceasing of these rift moverents shows a delay from north to south, similar to that at the beginning, about $7 \mathrm{~m} . \mathrm{y}$. In group I ( 72 to $65 \mathrm{~m} \cdot \mathrm{y} \cdot \mathrm{b} \cdot \mathrm{p} \cdot \mathrm{i}$ anomalies $31-26$ ), about more than $5 \mathrm{~m} \cdot \mathrm{y}$. (70 to $65 \mathrm{~m} \cdot \mathrm{J} \cdot \mathrm{b} \cdot \mathrm{p}_{0}$; anomalies $29-26$ ) in group II.

It should be noted that at the decay of the rotation the movement overlapped the next more southern group, which means that the rotation of groups I and II at the time of anomaly 26 only ceased south of the Mendocino F.Z. or south of the Moloksi F.Z., respectively, instead of north of it.

From north to south, the time of rotation included in

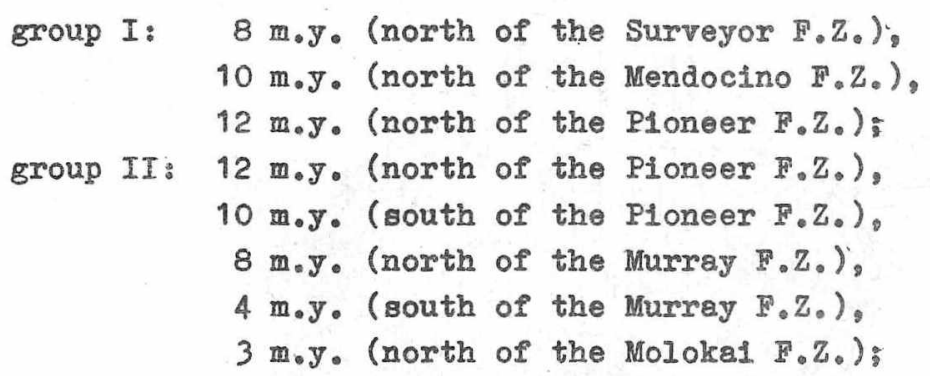

In the ares of the Mendocino and Pioneer $F_{0 .} ._{0}\left(38^{\circ}\right.$ to $\left.42^{\circ} \mathrm{N}_{0}\right)$, and at the rift section south of the Moloka1 F.Z. $\left(20^{\circ}\right.$ to $\left.22^{\circ} \mathrm{N}_{0}\right)$, the rotation of the rift was longest, $i_{.} e_{.}$about $12 \mathrm{~m} . y_{\circ}$, with the following highest amounts of rotation: $10^{\circ}$ in the area around $40^{\circ} \mathrm{N} ., 18^{\circ}$ in the area around $21^{\circ} \mathrm{N}$. , whereas at the other rift sections the maximum rotation was $5^{\circ}$.

The intensity of the first clockwise rotation was low, but with $1.5^{\circ} / \mathrm{m}$. y. south and north of the Molokai F.Z. It attained values approaching such of the great clockwise rotation about $60 \mathrm{~m} \cdot \mathrm{y} \cdot \mathrm{b} \cdot \mathrm{p}$. (Fig. 4). On an average, the rotations 60 to $50 \mathrm{~m} \cdot \mathrm{y} \cdot \mathrm{b} \cdot \mathrm{g}$. south of today $40^{\circ} \mathrm{N}$. (between Mendocino and Clarion $\bar{F}_{\circ} Z_{.}$s) reached up to $1.9^{\circ} / \mathrm{m}_{\circ} \mathrm{y}_{\circ}$,

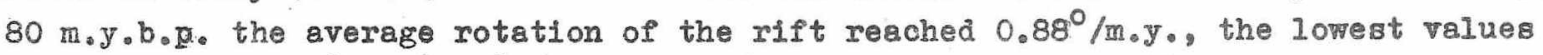
being between $0.3^{\circ}$ and $0.5^{\circ} / \mathrm{m} . \mathrm{y}$. (individual values of. Fig. 3 ).

2.2. The counterclockwise rotation of the N.E. Pacific Rift from 71 to $63 \mathrm{~m} \cdot \mathrm{y}, \mathrm{b} \cdot \mathrm{p}$. (2nd period)

The end of the clockwise rotation was identical with the beginning of the immediately following counterclockwise one. Owing to the time delay of the beginning these rift rotationa between $20^{\circ}$ and $52^{\circ} \mathrm{N}$. comprised altogether $8 \mathrm{moy}$. (anomalies 30 to 25). The maximum period of rotation on a single rift section vaxied, however, between 4 and $1.5 \mathrm{~m} \cdot \mathrm{y}_{0}$ only $\left(71\right.$ to $\left.63 \mathrm{~m} \cdot \mathrm{y} \cdot \mathrm{b}_{\circ} \mathrm{p}_{\circ}\right)$. In spite of the short duration the rotation was remarkably intense. At the rift aections from north to south the average angles of rotation (individual values cf. Flg. 3, right) were: $3^{\circ}-6^{\circ}-7^{\circ}$ - gmallex then $2^{\circ}$ - amelier than $2^{\circ}-9^{\circ}-12^{\circ}-8^{\circ}\left(3^{\circ}-5.3^{\circ} / m_{0} y_{*}\right.$, with the exception of the rift section between the Murray and Ploneer F.Z.E, whlch exhibits special characteristics). Thus the rate of rotation $70 \mathrm{~m} \cdot \mathrm{y} \cdot \mathrm{b} \cdot \mathrm{p}$. has been greater than 60 to $50 \mathrm{~m} \cdot \mathrm{y} \cdot \mathrm{b}, \mathrm{p}$. , at the time of the great well-known clockwise rotation. The rift almost made a jump, or ra- 
ther, it jumped in its individual sections. However, the average rate of rotation of the individual rift sections exceeded, with $3.08 \% / \mathrm{m} . \mathrm{y} .70 \mathrm{~m} . \mathrm{y}$. ago, the highest value of $3 \% / m_{0} y_{0}$ attained by the rift section north of the Mendocino F.Z. 50 m.y. ago (average rate of rotation of all individual parts at this time: $\left.1.63^{\circ} / \mathrm{m}_{0} \mathrm{y}_{0}\right)$.

The end of this rift movement show the same time delay from north to south (about $\left.4 \mathrm{~m} . \mathrm{y}_{\circ}\right)$. During this time, about $65 \mathrm{~m} \cdot \mathrm{y}$. ago, the Pioneer F.z. separated the East Pacific Rift between $20^{\circ}$ and $50^{\circ} \mathrm{N}$. Into a northern and a southern half (Figs. 3 and 8 ), with a coherent rotation.

It is striking that the delay with which a rotation began alwayg became shorter. The average value was at the

\begin{tabular}{|c|c|}
\hline inning 0 & $9 \cdot \mathrm{m} \cdot \mathrm{y}$ \\
\hline $\begin{array}{r}\text { end of cloc } \\
\text { countercloc }\end{array}$ & $6 \cdot m \cdot J$ \\
\hline e rotation (about $65 \mathrm{~m} \cdot \mathrm{y} \cdot \mathrm{b} \cdot \mathrm{p}_{\bullet}$ ) & 4.In॰Y.s \\
\hline$\left(60 m_{\bullet} y_{\bullet} b_{\bullet} p_{\bullet}\right)$ & 2.5 \\
\hline ut $\left.50 \mathrm{~m} \cdot \mathrm{I} \cdot \mathrm{b} \cdot \mathrm{p}_{\odot}\right)$ & $2 \mathrm{~m}_{\bullet} \nabla_{\bullet}$ \\
\hline
\end{tabular}

One out of many factors reducing the periods of time in which a new rift rotation started could be the increasing decoupling of the Pacific Plate from the Kula Plate. Owing to the N.E. movement of the triple point the Kula and Farallon Plates became more and more smaller and, consequently, their effects as a stabilizing element decreased. It may be that as a result of this process the Pacific Rift was more easily mobilized, which applied above all to the time following anomely 24 (60 m.J.b.p.). The Kula Rift more and more came into the position of a subduction zone, and the Faralion Plate remained less and less clamped in the angle between the Kula-Farallon Rift and East Pacific Rift.

2.3. Rotations of the rift during a trangitional stage about 65 to $60 \mathrm{~m}, \mathrm{y} \cdot \mathrm{b}, \mathrm{p}$. (3rd period)

The movements of the rift between 65 and $60 \mathrm{~m} \cdot \mathrm{y} \cdot \mathrm{b} \cdot \mathrm{p}$. differed essentially in their intensities, durations and directions of rotation. They must be attributed to a transitional atage preceding the beginning of the great clockwise rotation 60 to $50 \mathrm{~m} . \mathrm{J} \cdot \mathrm{b} \cdot \mathrm{p}$.

In Table 1 the rotations of this time are specified for the whole N.E. Pacific Rift from $20^{\circ}$ to $45^{\circ} \mathrm{N}$, and include a period from 3 to. $7 \mathrm{~m} . \mathrm{y}$. The rotations, for example, are

(a) alow, persiating then somewhat longer, e.g., anomalies $27-24$ north of the Surveyor F.Z., $7 \mathrm{~m} \cdot \mathrm{y}$. with a rotation rate of $0.3^{\circ} / \mathrm{m} . \mathrm{y} \cdot$,

(b) intense, but often of a short duration only, e.g., anomalies 26 - 25 north of the Molokai F.Z., $1.5 \mathrm{~m} . \mathrm{y}$. Iong with a rotation rate of $4^{\circ} / \mathrm{m} . \mathrm{y}$. 


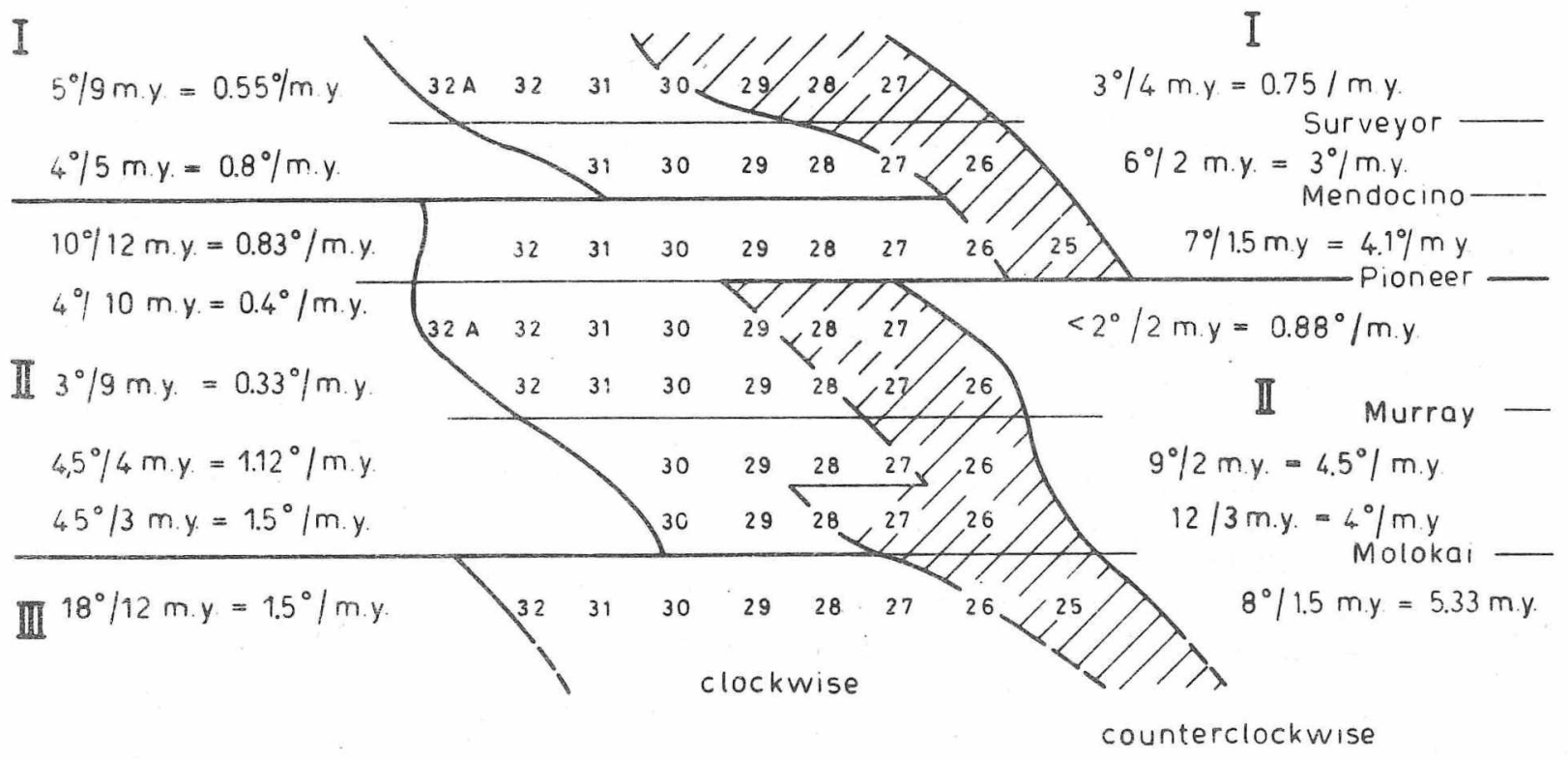

Fig. 3. Time scheme of rift rotations between 80 and $63 \mathrm{~m} . y_{\circ} b_{\circ} p$. ( 1 st and 2 nd periods). Wumerals: numbers of anomalies; left-hand side: clockwise rotation: xight-hand side: counterclockwise rotation (hatched)

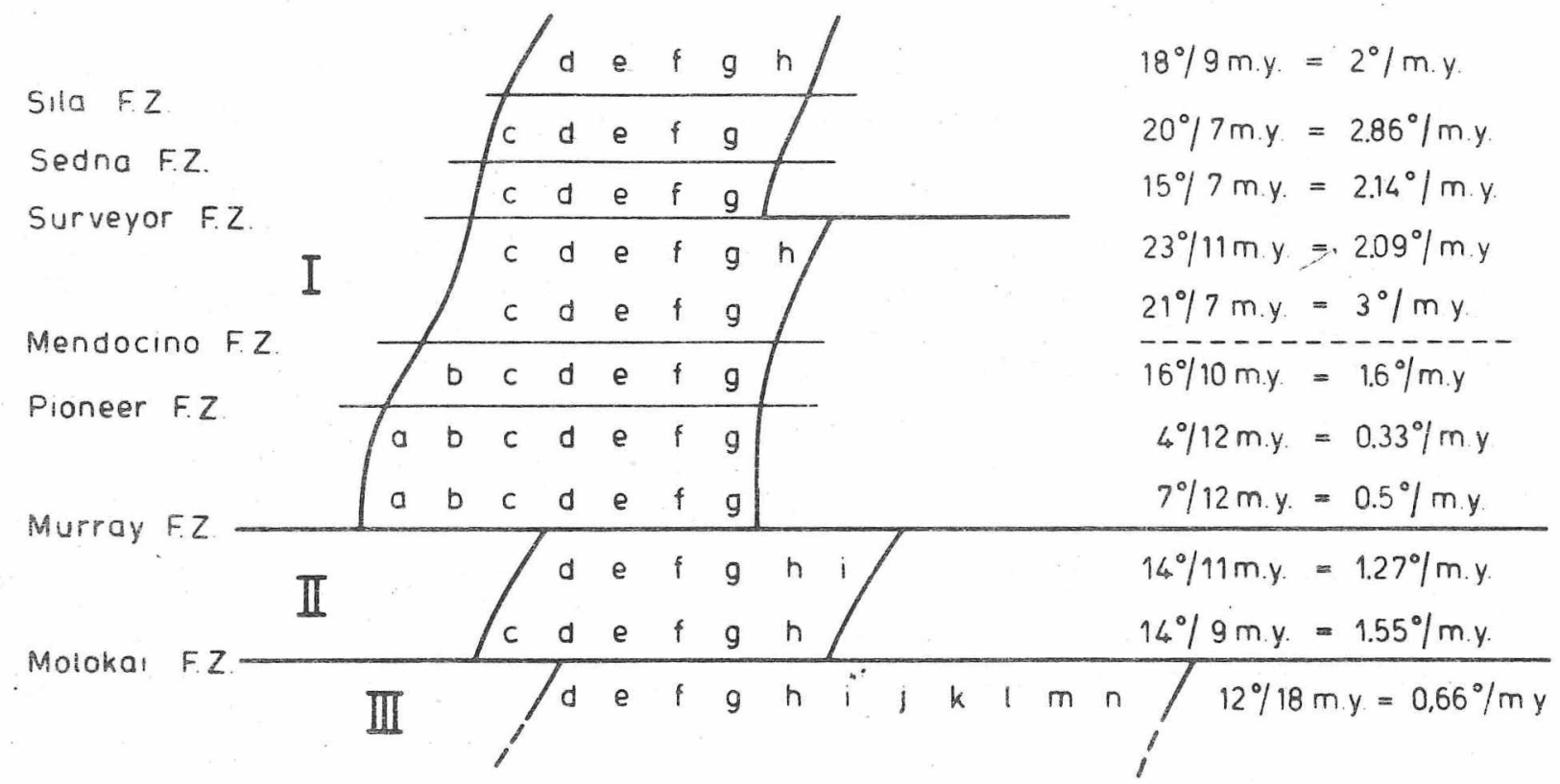

Fig. 4. Time scheme of the great clockwise rotation of the Erst Pacific Rift between 63 and $50 \mathrm{~m}, \mathrm{y}, \mathrm{b} . \mathrm{p}$. Latters: anomalies $(\mathrm{a}, \mathrm{b}=26,25 ; \mathrm{g}=21 ; \mathrm{n}=15)$ 
Table 1. Transitional atage $65-60 \mathrm{~m} \cdot \mathrm{y} \cdot \mathrm{b} \cdot \mathrm{p}$. (3rd period)

\begin{tabular}{|c|c|c|c|c|c|c|c|}
\hline & Anomalies & $\begin{array}{l}\text { Time } \\
\text { Lm.V.b.P.] }\end{array}$ & $\begin{array}{l}\text { Type of } \\
\text { rotation }\end{array}$ & Angle & $\begin{array}{c}\text { Rotation } \\
\text { within } 1 \mathrm{~m} . \mathrm{y} .\end{array}$ & $\begin{array}{c}\text { Duration } \\
{[\mathrm{m} \cdot \mathrm{Y} \cdot]}\end{array}$ & \\
\hline \multirow{2}{*}{ Surveyor F.Z. } & $27-14$ & $67-60$ & right & $2^{\circ}$ & $0,3^{\circ}$ & 7 & \\
\hline & $26-25 / 25-24$ & $64.5-63.5 / 63.5-60.5$ & Iolght $/=$ & $1.5^{\circ} /=$ & $0,5^{\circ} /=$ & $3 / 1.5$ & EsflfIII \\
\hline \multirow{2}{*}{ Mendoeino F.Z. } & $25-24$ & $63.5-60.5$ & right/left & $4^{\circ} / 6^{\circ}$ & $2^{\circ}: / 6^{\circ} ?$ & 3 & \\
\hline & $25-24$ & $\begin{array}{r}63.5-60.5 \text { the great } \\
\text { rotation is }\end{array}$ & $\begin{array}{l}\text { lockwise } \\
\text { beginning }\end{array}$ & $5^{\circ}$ & $3 \cdot 3^{\circ}$ & 1.5 & \\
\hline Pioneer F.Z. & $27-15$ & \multicolumn{3}{|c|}{ 67-50 only compensating rotations } & & 17 & \\
\hline \multirow{3}{*}{ Murray F。Z } & $28-11$ & \multicolumn{3}{|c|}{ 68-34 only compenseting rotations } & & 24 & - \\
\hline & $26-25 / 25-23$ & $64.5-63 \cdot 5 / 63.5-58.5$ & right/left & $2^{\circ} / 6^{\circ}$ & $1.33^{\circ} / 1.2^{\circ}$ & $1.5 / 5$ & \\
\hline & $26-25 / 25-24$ & $64.5-63.5 / 63.5-60.5$ & right/left & $6^{\circ} / 6^{\circ}$ & $4^{\circ} / 2^{0}$ & $1.5 / 3$ & \\
\hline Molokai F.Z. & $26-23$ & $64.5-58.5$ compensat & ing rotatio & & & 6 & \\
\hline
\end{tabular}


In general, they were not only of a shorter duration but also changed their senge of rotation within a short time, so that they oliminated each other in part, or almost completely, for example, the rotation at $27^{\circ} \mathrm{H}$. north of the Molokal F.2., about 64 to $60 \mathrm{~m} \cdot \mathrm{y} \cdot \mathrm{b} . \mathrm{p}$. A clockwire rotation of $6^{\circ}$ (anomalies 26 - 25) within $1.5 \mathrm{~m} .7_{\circ}$, which means a rotation of $4^{\circ} / \mathrm{m}_{\circ} y_{\mathrm{s}}$, was followed by a counterclockwise one of $6^{\circ}$ (anomalies 25 - 24) within $3 \mathrm{~m} . \mathrm{y}_{0}\left(2^{\%} / \mathrm{m}_{0} \mathrm{y}_{0}\right)$.

For the rift parts altogether then the great clockwise rotation in the area of the Pioneer and Mendocino $F_{0} 2_{\text {. }}$ was already initiated (cP. Fig. 4). In our opinion, 1t may be recognized that this time interval of 65 to $60 \mathrm{moy} \cdot \mathrm{b} . \mathrm{p}$. was already a kind of precursory. phase for the following great clockwise rotation, because

(1) north of the Survegor $\mathrm{F}_{0} \mathrm{Z}_{0}$, between $44^{\circ}$ and $55^{\circ} \mathrm{No}$, a slow but continuous clockwia rotation of the rift took already place during the time of the anomalies 27 to $24:$

(2) south of the Mendocino $\mathrm{F}_{0} \mathrm{Z}_{0}$, at $38^{\circ}$ to $40^{\circ} \mathrm{N}$, the great clockwise rotation $21-$ ready begen with anomely 25 (Fig. 2) $63.5 \mathrm{~m}, \mathrm{y} \cdot \mathrm{b}, \mathrm{g} \cdot(3.3 \% \mathrm{~m}, \mathrm{y} \cdot \mathrm{l}$ ):

(3) the centrel rift section in apite of the oscilleting movementa of the rift rotated at $32^{\circ}$ to $38^{\circ} \mathrm{N}$. between the Mirrrey and Ploneer $\mathrm{F}_{0} \mathrm{Z} . \mathrm{s}$ about $4^{\circ}$ to the north $\left(0.8 \% \mathrm{~m}_{\mathrm{e}} \mathrm{y}_{\mathrm{o}}\right)$, and this on account of the residual amounts of the oscillating movements,

From 80 to 40 m.y.b.p. thi central rift section was affected by a continuous clockwise rotatiou superimposing all ita pendulum movements (Fig. 8). As a result, 60 m.y. b.p.o the position of the rift at $40^{\circ} \mathrm{N}$, again appeared to be kinked more conslderably at the Ploneer F.Z., the rift to the north ahifted in a counterclockwise rotation. The same if valid for the rift sections gouth and north of the Holoks $F_{0}$. ot $25^{\circ} \mathrm{N}$. DurIng this superordinate clockwlae rotation of the total rift the kink points were shlfted In an eastern direction. The amount of rotation of the rift movements is represented in Fig. 8 and seems equally to be realized atep by step on a large diftance along the

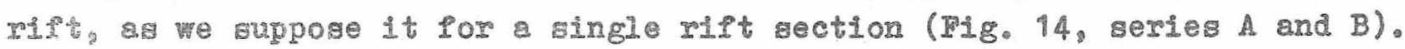

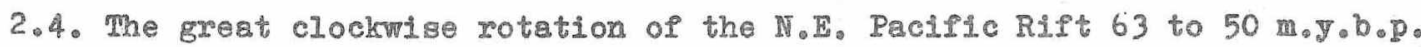 (4th period)}

Together with the clockwise rotation $7 \mathrm{~m} . y_{\circ} \mathrm{b} \cdot \mathrm{p} . \mathrm{o}$, the recond clockwle rotation of

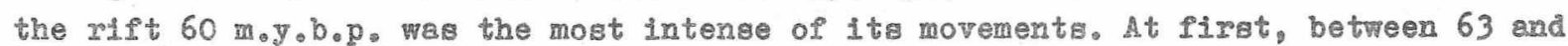
$60.5 \mathrm{~m} \cdot y_{\circ} \mathrm{b}_{\circ} p_{0}$, the triple point of the Kuls and North Paclile Rifts junped when about more than 2.5x... km. At that time, the hypothetical Kula-Faralion Rift had so much approeched a aubduction zone, and had so much been reduced, that a greater degree of freedor of nom tion of the N.E. Pacific Rift might have been involved. This is the time (about 61 $m_{\circ} y_{\circ} b_{\bullet} p_{0}$ ) when the great clockwise rotation began (enomalies 24 to $21-20$ ).

Fig. 4 shows the time delay at the beginning of thil Irtft rotation. The Mendocino

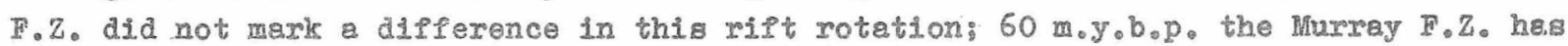
subdivided the movement at (today): $33^{\circ} \mathrm{N}$. North of the Murray $F \cdot Z_{0}$ the If fit foxmed a coherent block (I) with a continuous movement, where the rotation began in the south 
and, in the course of time, proceeded in a northern direction (BANKWITZ \& BANKWITZ 1972). The maximum time delay of the beginning rotation was $7 \mathrm{~m} . \mathrm{y}$. (from 65 to 58 m.J.b.p.). Then the rotation reached the rift section (II) between Murray and Molokai F.Z.a, beginning to rotate with anomaly $24\left(61 \mathrm{~m} \cdot \mathrm{y}_{\circ} \mathrm{b}_{\circ} \mathrm{p}_{\circ}\right)$ only $4 \mathrm{~m} \cdot \mathrm{y}$. later than the great northern block (I), its northerm partial section even at about $58 \mathrm{~m} \cdot y_{\bullet}$ only, i.e., $7 \mathrm{~m} \cdot \mathrm{y}$. later.

Therefore, the rift. sections south of the Murray F.Z. between $20^{\circ}$ and $33^{\circ} \mathbb{N}$. (present-day position), reacted with a clearly vigible delay towards the northern part of the plate between $33^{\circ}$ and $56^{\circ} \mathrm{N}$.

The duration of this rotation was different for the individual rift sections (7 to $12 \mathrm{~m} . \mathrm{y})$. The angle of rotation was between $23^{\circ}$ and $12^{\circ}$, and north of the 40 th degree N. was greater than south of it (Fig. 8). This also applies to the intengity of movement, being north of $40^{\circ} \mathrm{N} \cdot 2^{\circ}-3^{\circ} / \mathrm{m}_{0} \mathrm{y}_{0}$, south of it $1.6^{\circ}-0.7^{\circ} / \mathrm{m} \cdot \mathrm{y}_{0}$ (for individual values ce. Fig. 4). The average rate of rotation of this period was at $1.63^{\circ} / \mathrm{m} . \mathrm{y}$.

A special reaction is shown again by the aection between the Murray and Pioneer F.Z.B, between $33^{\circ}$ and $38^{\circ} \mathrm{N}$. (present-day position), with the longest rotation period of $12 \mathrm{~m} . \mathrm{y}_{\circ}$, the smallest angles of rotation of $4^{\circ}$ and $7^{\circ}$, and the smalleat intensities of $0.5^{\circ} / \mathrm{m} \cdot \mathrm{y}$. and $0.33^{\circ} / \mathrm{m} . \mathrm{y}$.

It is obvious that the end of the clockwise rotation again was retarded from south to north, just as during the slow counterclockwlse rotation 53 to $47 \mathrm{~m}, \mathrm{y} \cdot \mathrm{b}, \mathrm{p}$. (ano= malies 21 to 19) immediately following along the total rift between $20^{\circ}$ and $60^{\circ} \mathrm{N}$. From 80 to $60 \mathrm{~m} . \mathrm{y} \cdot \mathrm{b} . \mathrm{p}$. all rotations in the north of such a block began and proceeded towards the south. Since the East Pacific Rift has no longer been so intensely stabilized by the progressive subduction of the Kulamaralion Rift, it seems that the movements adopted an opposite course from south to north.

During the great clockwise rotation 60 to $65 \mathrm{~m} \cdot \mathrm{J} \cdot \mathrm{b} . \mathrm{p}$. the southemmost section between $21^{\circ}$ and $22^{\circ} \mathrm{N}$. Iost its rhythm and the rotation lasted here for $18 \mathrm{~m} . \mathrm{J}$. (58 to $40 \mathrm{~m} \cdot \mathrm{y} \cdot \mathrm{b} \cdot \mathrm{g} \cdot$, anomalies 23 - 15: Fig. 4). Thus the synchronous rhythm of rotation of the rift was intermpted between $20^{\circ}$ and $60^{\circ} \mathrm{N}$. As a result, this rift section "misaed" some events of the following 5 th and 6 th periods. This cersed In the successive counterclockwise and clockwise rotations (anomalies $15-14,14-10$ ), at todsy $23^{\circ} \mathrm{N}$. and $130^{\circ}$ to $123.5^{\circ} \mathrm{W}$. between the Clarion and Moloka1 F.Z.日 (Table 2), simultaneously corresponding, with some delay, to (1) the counterclockwise and clockwise rotations normally following (generally anomaly 20 to about 15) the great clockwise rotation, (2) on the other hand, already synchronously proceeding with the great counterclockwise rotation north of $40^{\circ} \mathrm{N}$. Prom 42 to $38 \mathrm{~m} \cdot \mathrm{y} \cdot \mathrm{b} \cdot \mathrm{p}$. (anomalies $16-13$ ), $8 \mathrm{~s}$ well as with the clockwise rotation south of $40^{\circ} \mathrm{N}$. from 39 to $22 \mathrm{~m} . \mathrm{J}$. (anomalies $14=10$, Table 2) and further (Fig. 5). In this way a syachronous behaviour of the rift sections wes again attained. 


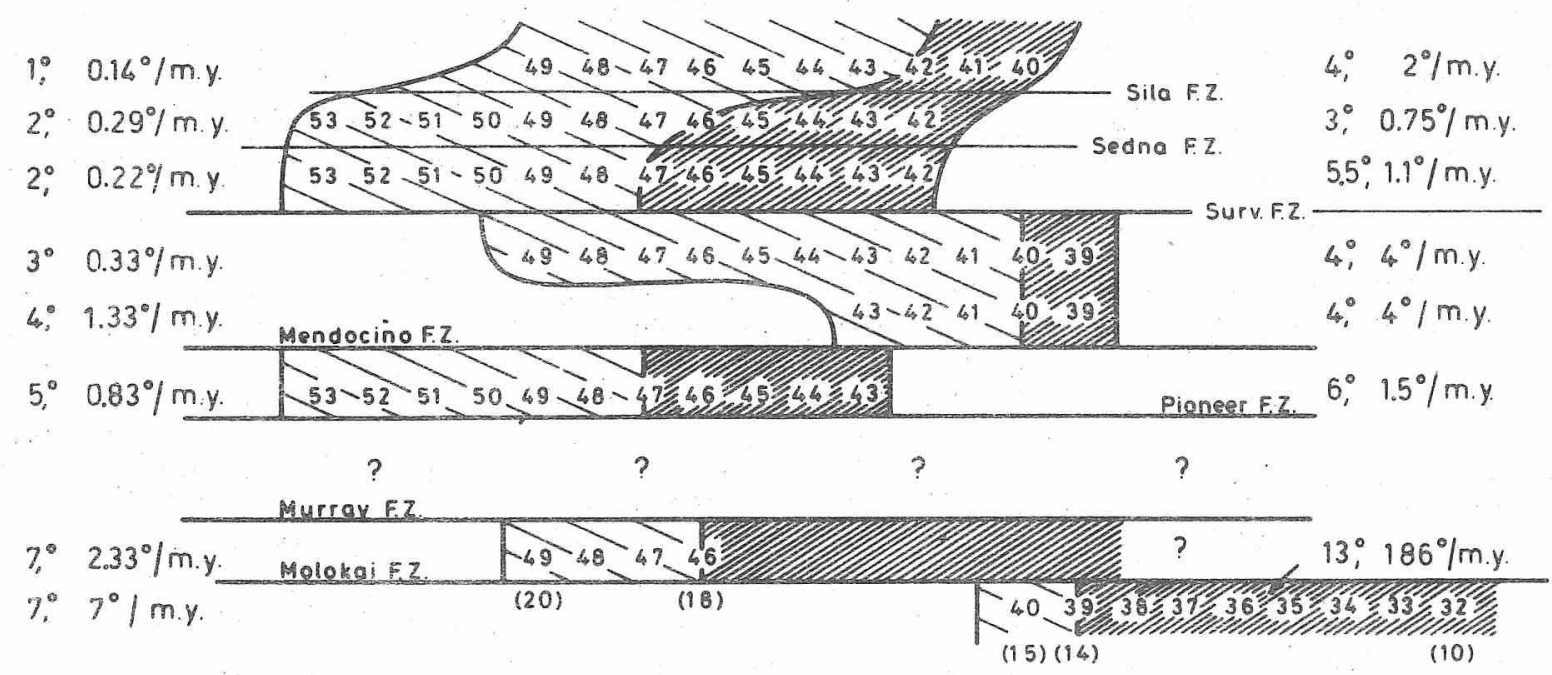

F1g. 5. Time schime of compensating rift rotations between 53 and $39 \mathrm{~m} . \mathrm{y} \cdot \mathrm{b} . \mathrm{p}$. (5th perfod). Hetches Inclined to the right and to the left: clockwiae or counterclockwise rotation, resp.

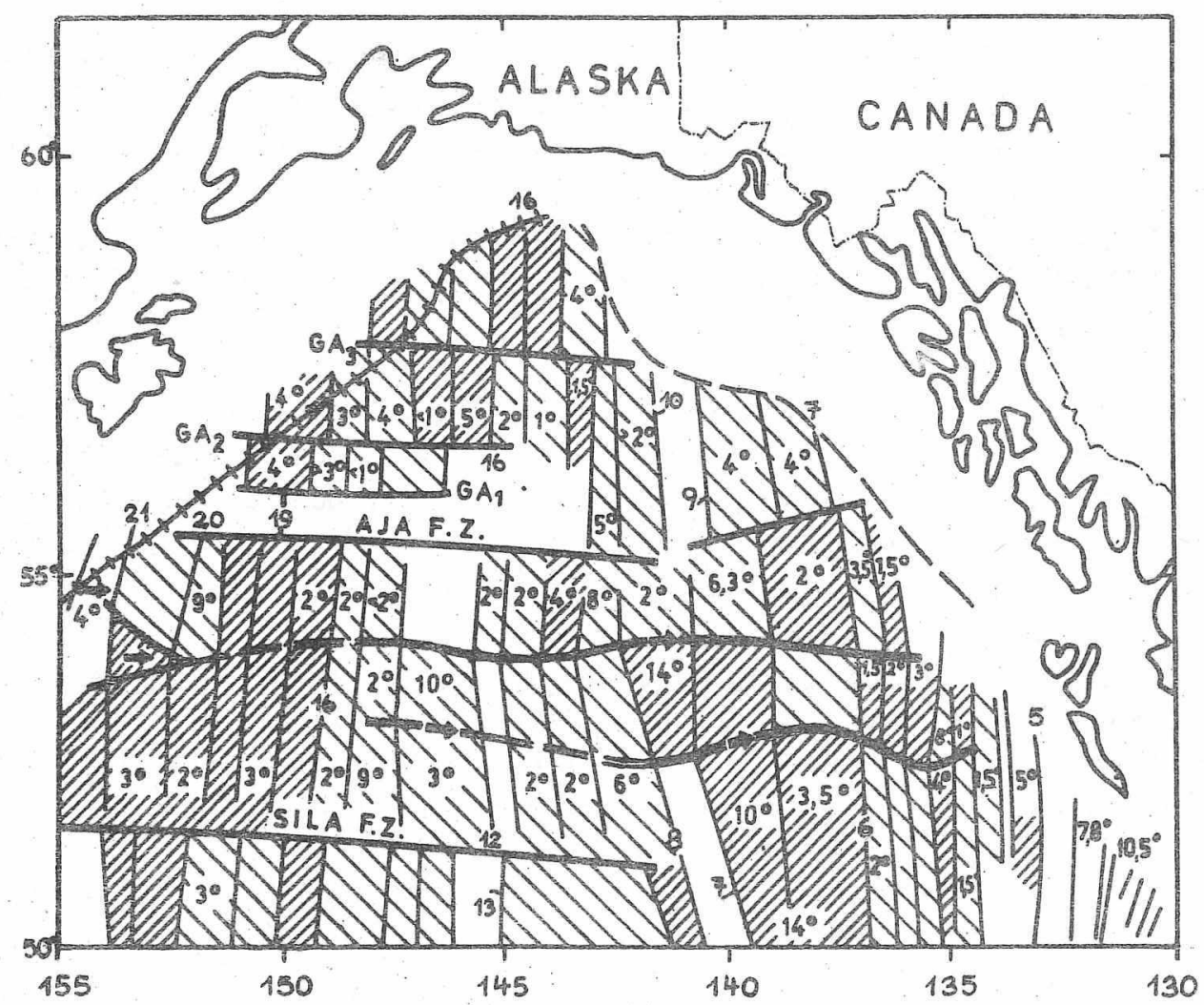

Fis. 6. Rotation of the Eest Pacifle Rift in the Gulf of Alagka. Anomalles after NAUGLER \& WAGERAT (1973). Nunerels: numbers of enomalies: degrees: rotation rates: two curved hinge lines between Agg and Sila F.Z.s aster BANKWITL. $\mathrm{GA}_{1-3^{\circ}}$ PaxIts 
Table 2. Superordinate rotations with a stabilizing function (5th period)

\begin{tabular}{|c|c|c|c|c|c|c|c|c|c|c|}
\hline & $\begin{array}{l}\text { Counter- } \\
\text { clockrise }\end{array}$ & $\begin{array}{l}\text { Rotation } \\
\text { in } 1 \mathrm{moy} \text {. }\end{array}$ & Anomalies & $\begin{array}{c}\text { Time } \\
{\left[m_{0} \mathrm{y} \cdot \mathrm{b}, \mathrm{p} .\right]}\end{array}$ & Duration & $\begin{array}{l}\text { Clock- } \\
\text { wise }\end{array}$ & $\begin{array}{l}\text { Rotation } \\
\text { in } 1 \text { m.y. }\end{array}$ & Anomalies & $\begin{array}{c}\text { Time } \\
{[\mathrm{m}, \mathrm{y} \cdot \mathrm{b} \cdot \mathrm{p}]}\end{array}$ & $\begin{array}{c}\text { Duration } \\
{\left[\mathrm{m}_{0} \mathrm{y}_{0}\right]}\end{array}$ \\
\hline $\begin{array}{l}\text { North of } \\
\text { Sila F.Z. }\end{array}$ & $1^{\circ}$ & $0.33^{\circ}$ & $20-16$ & $49-42$ & 7 & $4^{\circ}$ & $2^{\circ}$ & $16-15$ & $42-40$ & 2 \\
\hline $\begin{array}{l}\text { North of } \\
\text { Sedna F.Z. }\end{array}$ & $2^{0}$ & $0.31^{\circ}$ & $21-18$ & $53-46$ & 7 & $3^{0}$ & $\begin{array}{l}1^{\circ} \\
0.75^{\circ}\end{array}$ & $\begin{array}{l}18-17 \\
18-16\end{array}$ & $\begin{array}{l}46=43 \\
46-42\end{array}$ & $\begin{array}{l}3 \\
4\end{array}$ \\
\hline $\begin{array}{l}\text { North of } \\
\text { Surveyor F.Z. }\end{array}$ & $2^{\circ}$ & $0.33^{\circ}$ & $21-19$ & $53-47$ & 6 & $5.5^{\circ}$ & $1.1^{\circ}$ & $19-16$ & $47-42$ & 5 \\
\hline $\begin{array}{l}\text { South of } \\
\text { Surveyor F.Z. }\end{array}$ & $3^{0}$ & $0.33^{\circ}$ & $20-15$ & $49-40$ & 9 & $4^{\circ}$ & $4^{0}$ & $15=14$ & $40=39$ & 1 \\
\hline $\begin{array}{l}\text { North of } \\
\text { Mendocino } F \cdot Z_{\text {. }}\end{array}$ & $4^{\circ}$ & $1.25^{\circ}$ & $17=15$ & $43-40$ & 3 & $4^{\circ}$ & $4^{\circ}$ & $15-14$ & $40-39$ & 1 \\
\hline $\begin{array}{l}\text { North of } \\
\text { Pioneer F.Z. }\end{array}$ & $5^{\circ}$ & $0.83^{\circ}$ & $21-19$ & $53-47$ & 6 & $6^{\circ}$ & $1.5^{\circ}$ & $19-17$ & $47-43$ & 3 \\
\hline $\begin{array}{l}\text { South of } \\
\text { Pioneer F.Z. } \\
\text { North of } \\
\text { Nurray F.Z. } \\
\text { South of } \\
\text { Murray F.Z. }\end{array}$ & & & - & & & & . & & & \\
\hline $\begin{array}{l}\text { North of } \\
\text { Molokai F.Z. }\end{array}$ & $7^{\circ}$ & $2.16^{\circ}$ & $20-18 ?$ & $49-? 46$ & 3 & $13^{\circ}$ & & $? 18=?$ & ?46-? & \\
\hline $\begin{array}{l}\text { South of } \\
\text { Molokai F.Z. }\end{array}$ & {$\left[7^{\circ}\right.$} & $7^{\circ}$ & $15-14$ & $40-39$ & $1]$ & {$\left[13^{\circ}\right.$} & $1.88^{\circ}$ & $14-10$ & $39-32$ & $7]$ \\
\hline
\end{tabular}


2.5. Rotations with a stabiliging function in a transitional stage from 50 to $40 \mathrm{~m} \cdot \mathrm{y} \cdot \mathrm{b} \cdot \mathrm{p}$. (5th period)

The great clockwige rotation was followed by a kInd of trangitional stage in the period between approximately 50 and $40 \mathrm{~m} . \mathrm{y}$. before the rift entered the new period of a great counterelockwise rotation north of the 40 th degree $\mathbb{N}$. (Mendocino . $_{0} \mathrm{Z}_{0}$ ) and of a new clockwise rotation later on south of it. The rotations of this tranattional pexiod proceeded in a synchronous way along the whole rift (apart from the central section between $33^{\circ}$ and $38^{\circ} \mathrm{N}$. already mentioned repeatedly). The durations, angles of rotation and intensities are listed in Table 2.

A slow, long-listing counterclockwise rotation (with on average duration of about $6 \mathrm{~m} . \mathrm{y}$. and an average rate of rotation of $\left.0.8 \% \mathrm{~m}_{\circ} \mathrm{y}_{\circ}\right)$ is replaced by a more intense, shorter clockwise rotation (with an average duration of $2.7 \mathrm{~m} . \mathrm{y}$. and an average intensity of $2 \% \mathrm{~m} . \mathrm{y}$.$) . In both cases the angle of rotation increased from north to south$ (Table 2). The clockwise rotation began at a later date, about $43 \mathrm{~m} \cdot \mathrm{y}$. ago, nearly eliminating the preceding counterclockwise one at about $50 \mathrm{~m} . \mathrm{y}$. ago. By the remaining residual angles the rift wa: again clockwise rotated by about $1^{\circ}$ to $6^{\circ}$ altogether.

In our opinion the function of these rift rotations between about 50 and $40 \mathrm{~m} . \mathrm{y}$. ago was a compensating one and atabilized the plate (slowing down, inter alla, the clockwise tendency). These rotations, al though having an oscillating character effective for more than $10 \mathrm{~m} . \mathrm{y}_{.}$, belong to those being superordinate because they were related to the whole rift described here from $20^{\circ}$ to $60^{\circ} \mathrm{N}$. along several thousand $\mathrm{km}$.

2.6. The great counterclockwise rotation 43 to $20 \mathrm{~m}, y \cdot b \cdot p$. (6th period)

The great counterclockwise rotation only covered the northern part north of $38.5^{\circ}$ and $40^{\circ} \mathrm{N}$. (today), respectively, where it lasted for more than $20 \mathrm{~m} . \mathrm{y}$. (anomaliea 17 to 6). At first, the southern pert meintalned an indifferent attitude during this time, with compensating movements at the individuel rift parts for more then $3 \mathrm{~m} . \mathrm{y}$. from 4.3 to $40 \mathrm{~m} \cdot y_{\circ} b \cdot p$. (anomalies 17 to 15 ). Then a slow but uniform clockwise movement began.

The great counterclockwise rotation simultaneously started $43 \mathrm{~m} . \mathrm{y}$. ago at (today)

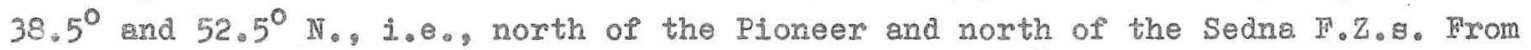
there the rotation proceeded in two groups (I and II) towards the north, where the last rift sections, south of the Sedna $F_{0} \mathrm{Z}$. and south of the coast of Alaska, were Included in this rotation at $58.5^{\circ} \mathrm{N} \cdot 3 \mathrm{~m} . \mathrm{J}$. later. In the area around $56^{\circ}$ and $57^{\circ}$ (Aja F.Z.: Fig. 6) identifled anomalies are miasing (NAUGLER \& WAGEMAN 1973). Therefore, 1t cannot be decided whether the area north of the Aja F.2. formed an independent unit of morement. Fig. 7 shows the anomalies with a counterclockwise rotation. (small letters) and the clockwise rotation presented in inclined hatches. The counterclockwise rotation overlapped the Mendocino F.Z. southward as far as the Pioneer F.Z.

A northem and a southem half of the rift can be recognized: from 43 to $38 \mathrm{~m} \cdot \mathrm{y} \cdot \mathrm{b} \cdot \mathrm{p}$. at (today) $38.5^{\circ} \mathrm{N}$. divided by the Pioneer $\mathrm{F}_{0} \mathrm{Z}_{0}$, and from 38 to $0 \mathrm{~m} \cdot \mathrm{y}_{0}$ at (todey) $40^{\circ}$ $\mathbb{N}$. divided by the Mendocino F.Z. (Fig。 7 ). 


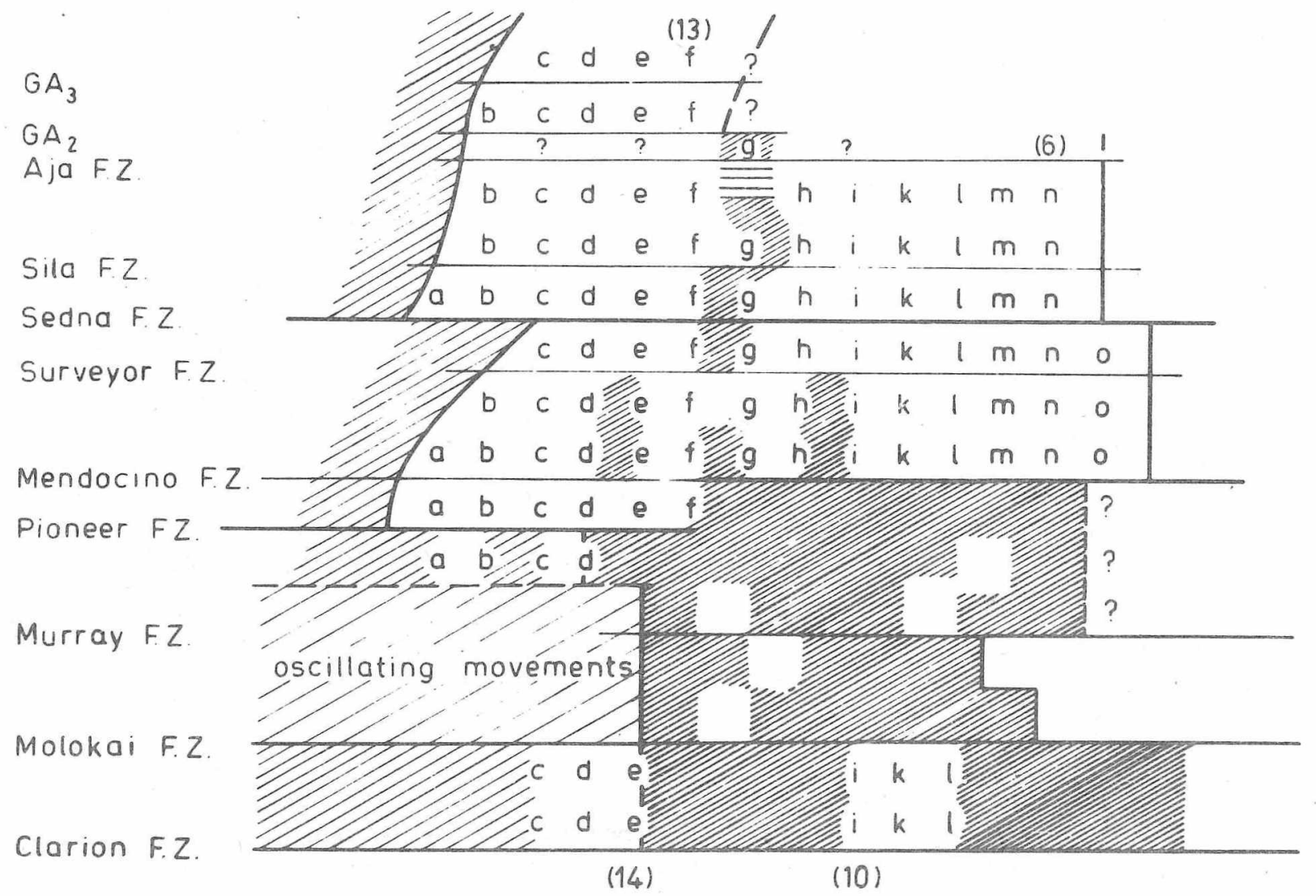

Fig. 7. Time scheme of the great counterclockwlse rotation of the East Pacific Rift between 43 and $20 \mathrm{~m} \cdot \mathrm{y} \cdot \mathrm{b} \cdot \mathrm{p}$. (6th period). Ietters: anomalies; numerals in brackets: numbers of anomalies; hatched: periods of clockwise rotation of rift sections

Thus there is again a hint on the special character of the double structure of the Pioneer and Mendocino F.Z.s, both of which share the Iunction of an intermal plate boundary, a function which definitely was accepted by the Mendocino F。2. Prom 38 m.y. b.p. As a result, the two rift parts were widely decoupled and almost independently reacted one upon another. This decoupling process began at $40 \mathrm{~m} . \mathrm{J}$. (anomaly 15) at the latest, and was terminated at $38 \mathrm{~m} \cdot \mathrm{g}$. (anomely 13). From $40 \mathrm{~m} \cdot \mathrm{y}$. onwards the two partis were subjected to a reorlentation, however, with an opposite aign.

The great counterclockwise rotation north of $38.5^{\circ}$ and $40^{\circ} \mathrm{N}$, reapectively, was interrupted by a atop of $3 \mathrm{~m}, \mathrm{y}$. only (at 38 to $35 \mathrm{~m}$. into two stages (anomalies 13 to 12 ), obviously a an effect of the clockwise rotation beginning at that time south of $40^{\circ} \mathrm{N}$. The beginning of the clockwise rotation south of $38^{\circ} \mathrm{N}$. (with $2^{\circ} / \mathrm{m}, \mathrm{y}$. almost an abrupt one) Is marked by another short stop within the counterclockwise rotation 40 to $39 \mathrm{~m} \cdot y_{\circ} b . p$. (anomalies 15 to 14). 
Table 3 show the angles of the rift rotation and their velocities an epproximate values. Although the rotation proceeded from gouth to north, the angles of rotation in the north $\left(51.5^{\circ}\right.$ to $54^{\circ} \mathrm{N}$.) being $14^{\circ}-10^{\circ}-24^{\circ}$ are three times those in the south $\left(40^{\circ}\right.$ to $\left.44^{\circ} \mathrm{N},\right), 4^{\circ}-3^{\circ}-7^{\circ}$. The increase towards the north was a continuous one.

It should be noted that, in spite of a much shorter duration of rotation of only $5 \mathrm{~m} . \mathrm{y}$. , the section between the Ploneer and Mendocino F.Z.日 also rotated by $7^{\circ}$, just as the more northem sections in an interval of 21 and $22 \mathrm{~m} . \mathrm{y}$. It seems that a rotam tion by $T^{0}$ was the minimum amount during the great counterclockwise rotation. The rotetion of the $1 \mathrm{st}$ atage from 43 to $38 \mathrm{~m} . \mathrm{y}$. was congiderably more intense ( $1^{\circ}$ to $\left.2.5^{\circ} / \mathrm{m}_{0} \mathrm{y}_{0}\right)$ than that from 38 to $21 \mathrm{m.y} \cdot\left(0.3^{\circ}\right.$ to $\left.0.4^{\circ} / \mathrm{m}_{0} \mathrm{y}_{*}\right)$. The stage 43 to $38 \mathrm{m.y}$. coincided with a counterclockwise rotation at the Reykjaner Ridge. There, the rotathos proceeded from north to south, at the N. Pacific Rift it proceeded from south to north.

The clockwise rotation from 40 to 32 and 27 m.J., respectively, south (today) $40^{\circ} \mathrm{N}$, has different durationg, namely.

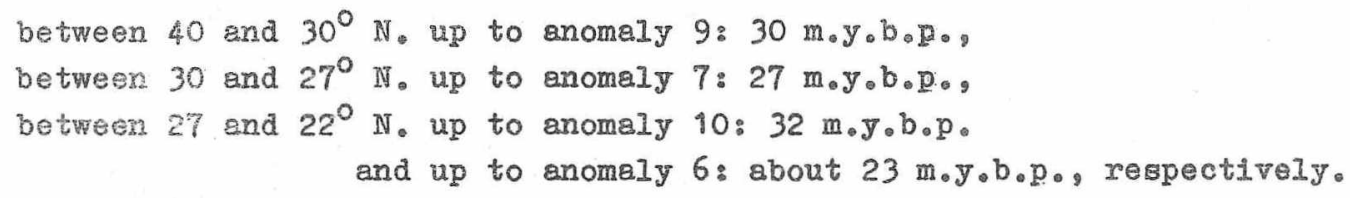

32 in.y. ago the Farelion Plate broke into two parti (ATWATER 1970). At the same fime the rift south of the Pioneer F.Z. abruptly rotated to $N . E_{0}$ by $30^{\circ}$ and $15^{\circ}$, res epectipely, within $2 \mathrm{m.y}$, which hints at a complete separation of the Farallon Plate ard the Northeast Pacific Rift, respectively.

The amounts of the clockwise rotation (Table 3) along the southern half of the rift are Iow, lying between $2^{\circ}$ and $5^{\circ}$, with average velocities from $0.2^{\circ}$ to $0.4^{\circ} /$ m.. . ex. cept for the sections at $38^{\circ}$ and $23^{\circ} \mathrm{N}$. with rotations of $16^{\circ}$ and $13^{\circ}$, respectively, and rotation rates of $2 \% / \mathrm{m} . \mathrm{y}$. and $1.71^{\circ} / \mathrm{m} . \mathrm{y}$. In the superordinate rotations we do not include that of the anomelies 10 to 9 by $30^{\circ}$ north of Murray $5 . Z$. 
Table 3. The great counterclockwise rotation $43-20 \mathrm{~m} \cdot \mathrm{y} \cdot \mathrm{b} \cdot \mathrm{p} \cdot$ ( 6 th period)

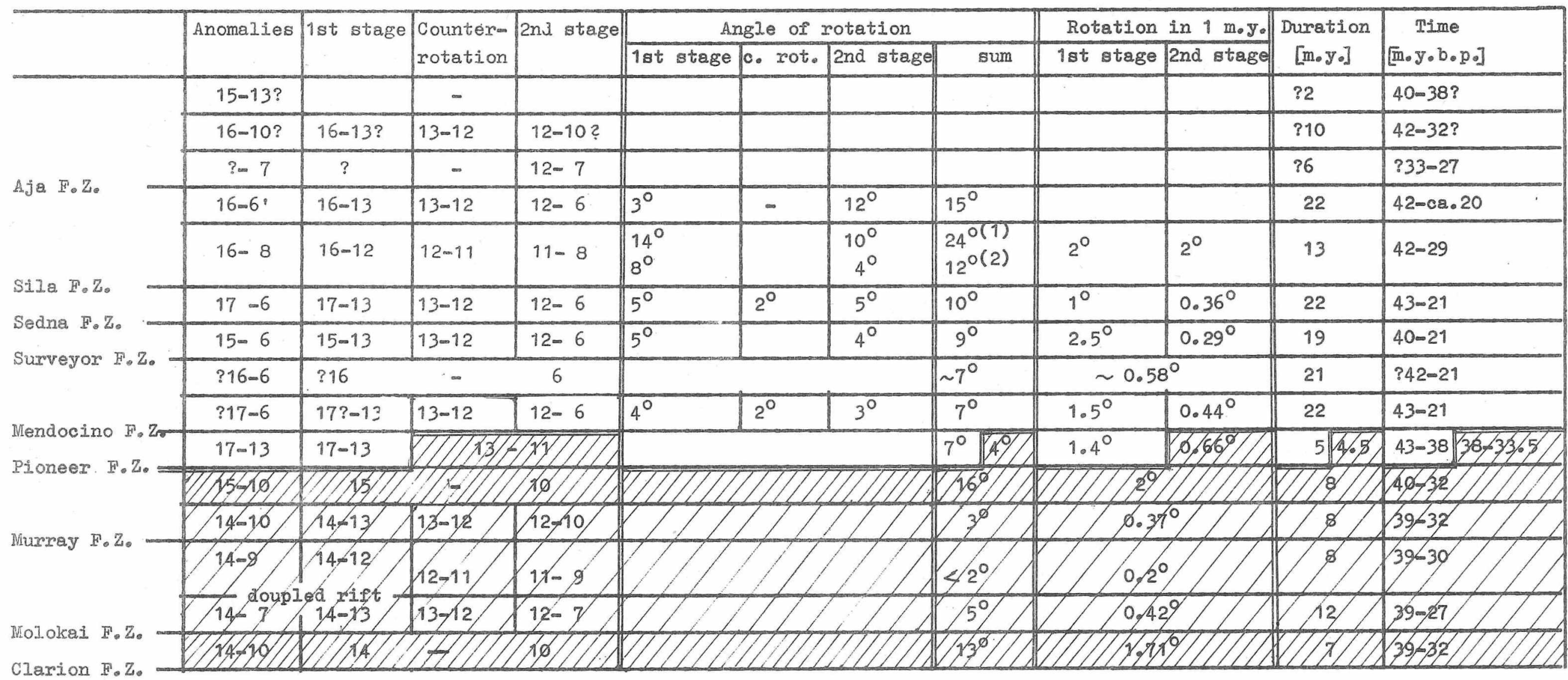

(1) after ITAUGLER \& WAGBMAN (1973);

(2) after ATWATER (1970) 
3. Total rotation of the East Paclfic Rift between Clarion and Aja Fracture Zones

Rifts are able to perform various movements at the ame time (ci. Section 5.1.). VAII ANDEL (1974) agumes that the Bast Pacific Plate rapidiy ahifted its boundary towarda east from $50 \mathrm{~m} . \mathrm{y} \cdot \mathrm{b} . \mathrm{p}_{\text {. }}$ to about $25 \mathrm{~m} . \mathrm{y} \cdot$, with the rift ahifting from $115^{\circ}$ to $105^{\circ}$ W. IARSON \& CHASE (1972) pregume a shift of the Bast Pacific Rift towards the eat from $150 \mathrm{~m} \cdot \mathrm{J} \cdot \mathrm{b} . \mathrm{p}$. $t 111$ today (Fig. 11). According to ATWATER (1370), an additional northward movement of the rift took place from 80 to $20 \mathrm{m.y} . \mathrm{b} . \mathrm{g}$. There movements were connected with rotationa, as can be concluded iror geometrical features of the anomalies between $20^{\circ}$ and $60^{\circ} \mathrm{N}$. Fault displacements (Fig. 8) were eliminated $a$ belng able to streas the importance of rotation for the movement of the total rift. Thus the general direction of the rift and its change due to rotations can better be reviewed.

3.1. Sum of rotations of the rift

Three superordinste tendencies can be distingulghed in the total behaviour of the roitt:

(1) the period frow 80 to $40 \mathrm{~m} \cdot \mathrm{y} \cdot \mathrm{b}, \mathrm{p}$.: Gtage of a clockwige rotation of $24^{\circ}$ to $11{ }^{\circ}$,

(2) period fron 40 to $20 \mathrm{~m} \cdot \mathrm{J}, \mathrm{b}, \mathrm{P} \cdot$ : stage of a counterclockwise rotation of $8^{\circ}$ to $2.5^{\circ}$, and

(3) period from 20 to 0 m.y.b.p.: stage of a clockwise rotation of $28^{\circ}$ to $24^{\circ}$.

Frow 80 to $40 \mathrm{m.y.b.p.} \mathrm{the} \mathrm{rift} \mathrm{in} 1 \mathrm{ts}$ whole length rotated at nearly the same time, In apte of Ita diaplacements at the frecture zones. From 40 to $20 \mathrm{~m} . \mathrm{y} \cdot \mathrm{b} . \mathrm{p}$. the north eIr and southern halves of the rift reacted in an opposite rotation sense. The reaaon le obviously not to be found in the rift divplacement at the linendocino F.Z., as it is demonstrated by the readjustment of the rift to a shift of the Pole of rotation with a general clockwiae rotation of the rift from $10 \mathrm{m.y.b.p.} \mathrm{up} \mathrm{to} \mathrm{now,} \mathrm{whlch} \mathrm{agein}$ covered the rift atill exiding: in the north the Juan de Fuca Rift, in the aouth the Rivera Rift. - It may be supposed that the cause of reorientation of the rift during the 2nd stage of rotation was more subordinate in nature then that of the 1 st stage.

During the 1 st stage, from 80 to $40 \mathrm{~m} \cdot \mathrm{y} \cdot \mathrm{b} . \mathrm{p}_{\circ}, \mathrm{a}$ clockwise rotation of $24^{\circ}$ superimposed the different movements of the whole rift during ivive periods of rotation (Chapter 2). It 1s obviously a readjugtment to a shift of the pole of rotation permanently going on, slowly for $20 \mathrm{~m} . \mathrm{y}$., jumping from 60 to $50 \mathrm{~m} . \mathrm{y} \cdot \mathrm{b} . \mathrm{p}$. with a rotation by $19^{\circ}$, gradually finishing 50 to $40 \mathrm{~m} \cdot y_{\circ} b_{\circ} p_{\text {. }}$ (Fig. 8). For the time of the great clockwige rotation (anomalies 24 to 20) this means a ahift of the rift by 4.5 $\mathrm{cm} / \mathrm{Y}$. , In addition to the spreading rate of 3 to $4 \mathrm{~cm} / \mathrm{y} .1,500 \mathrm{~km}$ north of the Mendocino F.Z. The Mendocino-Pioneer double structure behaved like a separating line that divided the rift into two parts reacing differently, with the southern half taking part in the rotation from 80 to $40 \mathrm{~m} \cdot y_{\circ} \cdot \mathrm{b} . \mathrm{p}$. , however, by about $11^{\circ}$ only.

Apart from the dipplacoments the rift, $80 \mathrm{~m}$.y.b.p. (anomaly 32), was kinked two times, towarda the east in the aree of the Mendocino F.Z., towards the west in the area of the Molokal. F. Z. The intenge clockwise rotation of $18^{\circ}$ south of the Molokai F.z. with the rate of $1.5^{\circ} / \mathrm{m}$. 


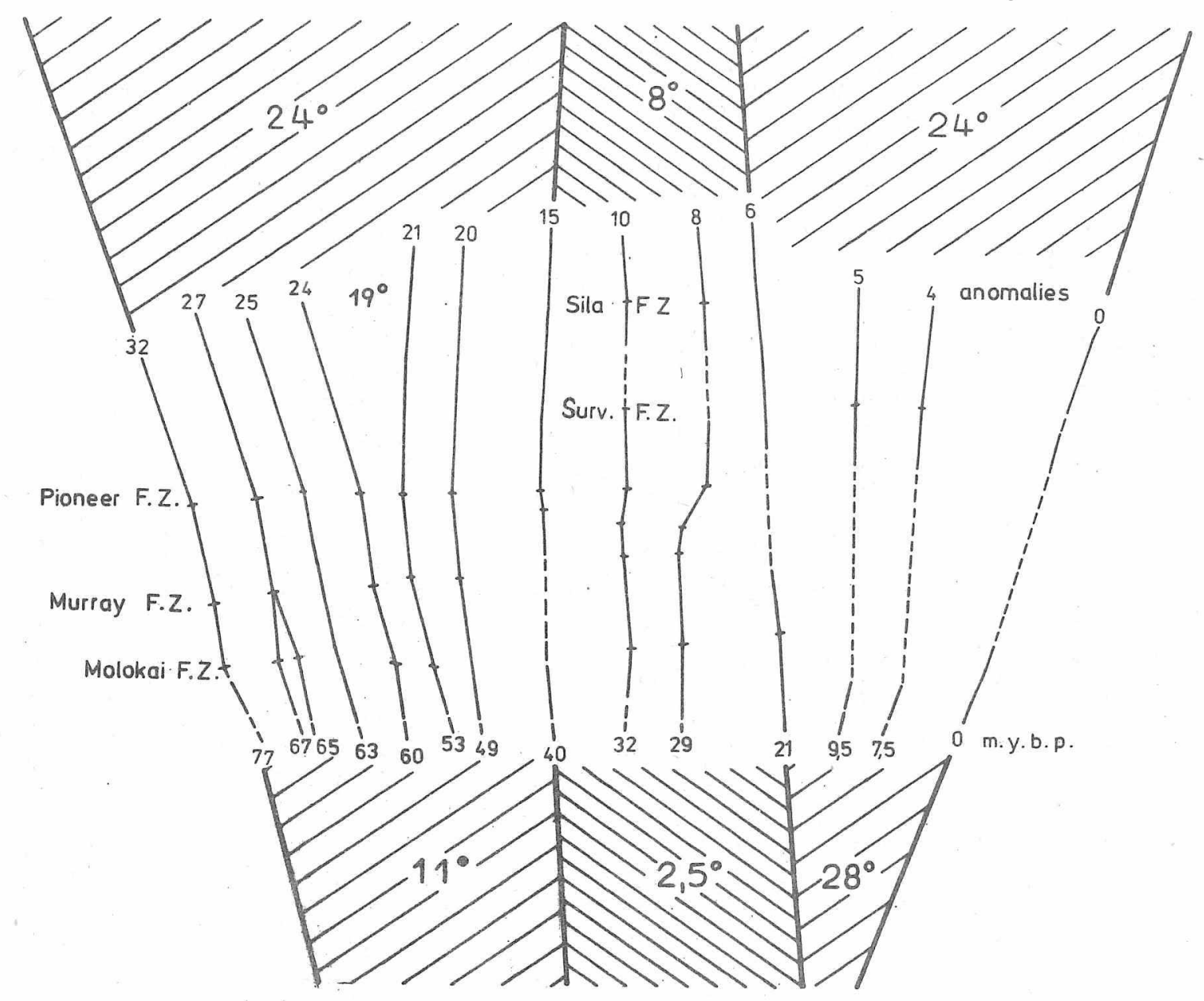

Fig. 8. Configuration of rift rections in the NoF. Pacific according to Fig. 1 of ATWATER 1970. Displacements are eliminated. Di.tances between rift positions are not tiken into account; three main rotations of the whole rift occurred: slockwise Iocation between 77 and 40 m.y.b.p. (anomaliea 32 - 15), countere clockwise rotation between 40 and $21 \mathrm{~m} \cdot \mathrm{y}$. (anomallea $15-6$ ), elockwise rotation between $21 \mathrm{~m} \cdot \mathrm{y}_{0}$ and today - with different rotation rater north and wouth of the Pioneer F.Z. 
rift for $15 \mathrm{~m} . \mathrm{y}$. , fust as the intense counterclockwise rotation of $12^{\circ}$ to $8^{\circ}$ with a rate of $4^{\circ}$ to $5 \%$ m.y. (anomailes $26-25$; Figs. 3 and 8). The rift, 63 m.y. 2go, was the best atraightened: this charecter was only attained again at 21 m.y.b.p. (anomaly 6), that is, 42 m. y. leter。

For the whole time the rift altogether newly orientated itaelf to maintain a pogition adjusted in the best way possible towards the pole of rotation, obviously ahifting continuously step by step. It is the question, however, (a) of the rote of delay In which this action took place, (b) of whether the three counterclockwse and four clockwse rotationa directly rellect variations of the pole position, 80 to 42 m.y. b.p. or (e) II they must be sttributed to other global processes, or (d) of whether the clockwive rotation resulting definitively by $24^{\circ}$ and $19^{\circ}$, respectively, only rew presented a reedjustront to the changing position of the pole. In this case intercalated countraclockw a rotatlons would only repreaent pendulum movements of the rith having a ztabilizing effect, or secondary movementr at hinges of the rift. This reletionship geems to be probable.

The manner In which a rotation of the whole rift is realized apeaks in favour of this opinion. First of all, the rift moved just as along hinger, that is to say, at deilnite fault pleces the rift rotated revercely at the southern and northern flanks, relatively, In the way 0.5 elong a hinge, e.g o, during the times of anomalier $27-24$

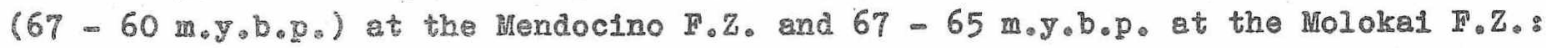
noxth of them moring in counterclockwise dixection and acth of them in an opposite direction (1st phase). At the ge hinges the rift synchronougly shifts eatward, which is ald the more conspicuour a at the po points the rift is separated by considerable displacements. In this wey the counterclockwise rotation of the northern Iimbs pretends to be a mecondary or compenssting rotation. In the 2nd phase only all gections of the rift were covered by a continuous clockwise rotation.

Generel rotationg of the whole rift (cf. Fig. 8):

\begin{tabular}{|c|c|c|c|c|c|c|}
\hline $\begin{array}{l}1 \text { gt phase } \\
\text { anomalies }\end{array}$ & $\begin{array}{c}\text { Time } \\
{\left[m_{0}, b_{0}, D_{2}\right]}\end{array}$ & $\begin{array}{c}\text { Duration } \\
{[\mathrm{m}, \mathrm{y}, \mathrm{i}}\end{array}$ & $\begin{array}{l}\text { 2nd phase } \\
\text { anomalies }\end{array}$ & $\begin{array}{l}\text { Time } \\
{\left[\mathrm{m}, \mathrm{y}_{0}, \mathrm{~b}, \mathrm{D}_{2}\right]}\end{array}$ & $\begin{array}{l}\text { Duration } \\
\text { [m.J.] }\end{array}$ & Reaultant \\
\hline $32-24$ & $80-60$ & 20 & $24=15$ & $60-40$ & 20 & clockwi̊se rotation \\
\hline $15-10$ & $40-32$ & 8 & $10-6$ & $32=21$ & 11 & $\begin{array}{l}\text { counterclockwise ro- } \\
\text { tation }\end{array}$ \\
\hline $6-5$ & $21-10$ & 11 & $5-0$ & $10-0$ & 10 & clockwise rotation \\
\hline
\end{tabular}

During the 2nd stage with muperordinate counterclockwis rotation of the whole Ift, 40 to 20 m. part by $2^{\circ}$ only. Owlng to the consequent clockwlae rotation from 38 to $32 \mathrm{~m} . \mathrm{y} . \mathrm{b}, \mathrm{p}$. (anomal1es $14-10)$ gouth of the Mendocino F.2. and the continuou countercloekwise rotation north of 1t, the rift again moved along the Mendocino-Ploneer atructure like on 9 hinge (FLg. 8). Al a reault of the hinge movement the rift previoualy kinked westward became kinked eastward, almost completely straightening ltgelf at the time of anomely $6\left(21 \mathrm{~m} . \mathrm{y} \cdot \mathrm{b} . \mathrm{p}_{0}\right)$ when all parts occupied a uniform position towerds the epreading pole. 
The $3 r d$ stage began $21 \mathrm{~m} . \mathrm{y}$. ago. It may be accepted that at that time, on account of the divisioning of the Farallon Plate, the rotation of the Rivera Rift in the south, $14^{\circ}$ and $18^{\circ}$, at anomalies 5 and 4 was twice as much as in the north $\left(6^{\circ}\right.$ and $\left.12^{\circ}\right)$. Only recently the rotation of the Juan de Fuca and Gorda Rifts $\left(24^{\circ}\right)$ has almost reached that of the southern Rivera Rift $\left(28^{\circ}\right)$, which means that in the last $4 \mathrm{~m} . \mathrm{y}$. the northern rift rotated by $3 \% \mathrm{~m} . \mathrm{y} \circ$, whereas in the south it seems that the fast rotation already finished $4 \mathrm{~m} . y^{3}$. ago. The high amount of rotation are obviously due in part to the collision between the Paclife and American Plater.

3.2. Special position of the plate section between $33^{\circ}$ and $37^{\circ} \mathrm{N}$.

An activity somewhat differing from the other part of the rift is shown by the section between the Murray and Pioneer $\mathbb{F}_{0} \mathrm{Z}_{\mathrm{g}} \mathrm{g}$ between $33^{\circ}$ and $38^{\circ} \mathrm{N}$, where the anomalies are arranged in a more regular and parallel manner. A remarkable rotation is misaing, the section being covered by the first clockwise rotation only of 80 to 70 m.y.b.P., with short rotations having an oscillating character, which we consider to be compensating movement of the rift, carried out for $30 \mathrm{~m} \cdot \mathrm{y}$. The rotations are slow

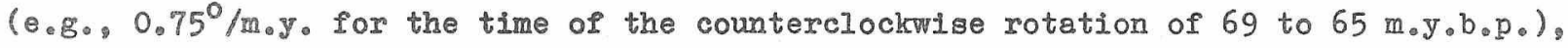
or rather of a short duration. As a rule, they were partly compensated in an opposite direction immediately afterwards.

In spite of these pendulum movements regidual amounts are summed up to a clockwise rotation conforming the dominant tendency of this rift section. Thus it rotated by $15^{\circ}$ from 77 to $32 \mathrm{~m}, y \cdot b . p$. altogether (anomelies 32 to 10 ; Fig. 8) still during the time of the general counterclockwise rotation of the whole rift from 40 to $20 \mathrm{~m} \cdot \mathrm{J} \cdot \mathrm{b} \cdot \mathrm{p}$. Consequently, this rift section 2ived a "life of its own" for $70 \mathrm{~m} . \mathrm{y}$. (anomaly 29), but fitted into the tendency of the whole rift and was, to a certain extent, the stabilized centre of the rift solely reflecting the real rates of rotation or the whole rift. The short-time counterclockwise rotations inserted in this clockwise rotation. may be regarded a movements stabilizing this plate section.

About $42 \mathrm{~m} . \mathrm{y}$. ago, the adjacent more southern section between the Murray and MolokaI F.Z.a presumably took upon itself the function of compensation by means of penduIum moverents. During the following time a second rift was formed parallel with it, which later became extinct again. This is a peculiarity of the rift under discussion.

\subsection{The Bignificance of the Mendocino-Pioneer double structure}

By the large faults known from the N.E. Pacific the rift is divided into parts displaced along these faults, $1_{0} e_{.}$, by which they are morphologically separated from one another. Regardless of this separation several sections often reacted simultaneously and coincidingly, unlike another group of rift sections. Figs. 3 to 5 and 7 show the fault heving an additional function to separate such groups which erert a uniform morement。 
Special importance must be attributed to the Mendocino $F_{0} \mathrm{Z}_{\text {. }}$, which separated the rift into two differently active parta, a role which it shared with the Pioneer $F$ runing parallel with it at a distance of 150 to $200 \mathrm{~km}$. Both faulta reacted like a double structure belonging to one another, whose external margins are formed by the Mendocino F.Z. and Pioneer F.Z., between them, however, 8 short section of the rift has always formed a new ocean floor. A similar result was obtained by VOGT \& AVERY (1974) for the Gibbs F.Z. in the AtIantic. A third double structure with spreading in the central stripe is the Eltanin F.Z. (HEIRTZIER 1968). We should like to include in thi. type the Nendocino-Pioneer zone, whose character is emphagized by Fig. 8.

The rift sections north of this zone behaved by far more symchronous and in the kind of movement they were much more in conformity than aouth of it. In Its movements 80 to $50 \mathrm{~m} \cdot \mathrm{y}_{\circ} \mathrm{b} . \mathrm{g}$. the small rift section between the Mendocino and PIoneer F.Z. $\mathrm{s}$ wa.s connected more to the north, later on more to the south, but changed and, in part, performed deviating movements. This stripe at leat formed a trangitionel area between the northern and goutherm parts of the Pacific Rift. 
C H I L E F P CTURE ZONE

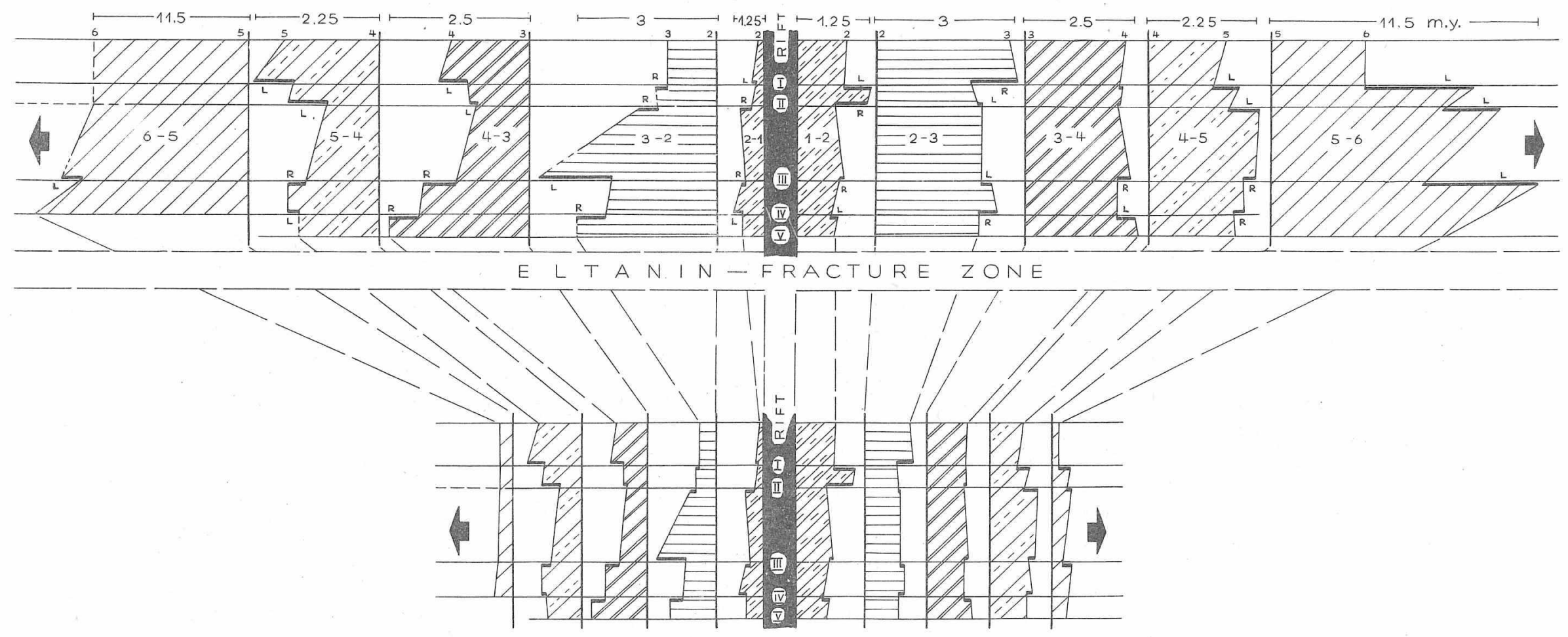

spreading / m.y.

Fig. 9. South Pacific Antarctic Rift between Chile and Eltanin F。 . $_{0}\left(30^{\circ}-65^{\circ} \mathrm{S}_{\circ}\right)$. A: Width or the anomalies $1-6$ : columns (the length of the rift ist reduced $1 ; 10$ ). B: width of anomalies/1 moyo Source: HERRON 1971 
4. Rotations of the Pacific-Antarctic Rift between $30^{\circ}$ and $65^{\circ} \mathrm{S}$.

4.1. Complex movements of the rift

According to HERRON (1971), the part of the Pacific-Antarctio Rift between the Chile F.Z. and Eltanin F:Z. shows almost all characteristics of a rift activity as mentioned in Chapter 5: rift drift, rit rotation, obliquity of anomalies vithout rotation, etc. The different rates of spreading (rift axis shortened, displacements eliminated) are demonstrated in Fig. 9. The thin cantre ine of the blocks in Fig. 10, series $A$ and $B$, correapond to anomaly Iimitations towards the roft in Fig. 9.

Fig. 9 indicater the variations of the fault activity for the individual faults at any time having another value and, for the most part, another direction of ahift (R: rotating clockwise. $L$ : rotating counterclockwise). The fault activity at the fault sections is mainly outside the transfom sections. The lower row of Fig. 9 ahows the spreading rate, a small general weat drift of the rift indicating itself by higher spreading rates on the east side.

In Fig. 10 (row $A$ and $B$ ), for example, the presumable position of the rift at the begining of the time between anomalies 5 and 6 is recorded a a thick line. Thin arrows indicate the direction in which the rift obviously rotated during this time, till it reached a position presumably occupied $9.5 \mathrm{m.y.b.p}$. mick arrows auggest the lateral shit to be simultaneously supposed for the rift, whose position, fror 9.5 m.y.b.p., was to be within the formed atripe, in the range of the thin central anis, because it merks the limitation of synchronous stripes east and west of the rift.

The northemmost section (Fig. 10) presumably drifted eastward from 20 to $7 \mathrm{~m} . y_{0}$ b.p., taking a reverae direction $7 \mathrm{~m} . \mathrm{y}$. ago. At first, it slowly drifted westward. then, $5 \mathrm{~m} . \mathrm{y}$. 8go, fartex, a tendency alowing dom aince $2 \mathrm{~m} . \mathrm{y}_{\text {. It }}$. aeme that this section, directly south of the Chile F.Z., was most intersely shifted 1aterally.

The central stripe between the fault II and III obvioualy drifted westward since $9.5 \mathrm{~m}_{0} \mathrm{y}_{0} \mathrm{~b}_{0} \mathrm{p}_{\mathrm{i}}$ thus, this movement began $3 \mathrm{~m} . \mathrm{y}_{\circ}$ before the east arift of-the northern part has ended and also turned into a west drift. With respect to drift and rotation. the parts north of the Eltanin F.Z. behaved most quiet. Between 5 and 2 m.y.b.p. the rotation of the central part of the rift and the weat shift of itg northern part point at a general counterclockwise rotation of the rift for $3 \mathrm{~m} . y_{\text {. In }}$ the 1ast $2 \mathrm{~m} . \mathrm{y} \cdot \mathrm{b} . \mathrm{p}$. a general west drift definitely covered the whole rift. These lateral shifts of the rift were partly accompanied by rotations of the sections.

The row C in Fig. 10 schematically indicates afferences in the activity of the individual rift section (intrusions intengified above the averege: basis of wedges; average production: apex of wedges). Here, too, areas with an intengified intrusive activity mostly lie at the end of a rift part, i.e., near fracture zonos, e.g., at the southern end of the central section between faults II and III for 7.5 m.y. ( 9.5 to $2 \mathrm{~m} \cdot \mathrm{y} \cdot \mathrm{b} . \mathrm{p} .$, anomalies 5 to 2 ). 

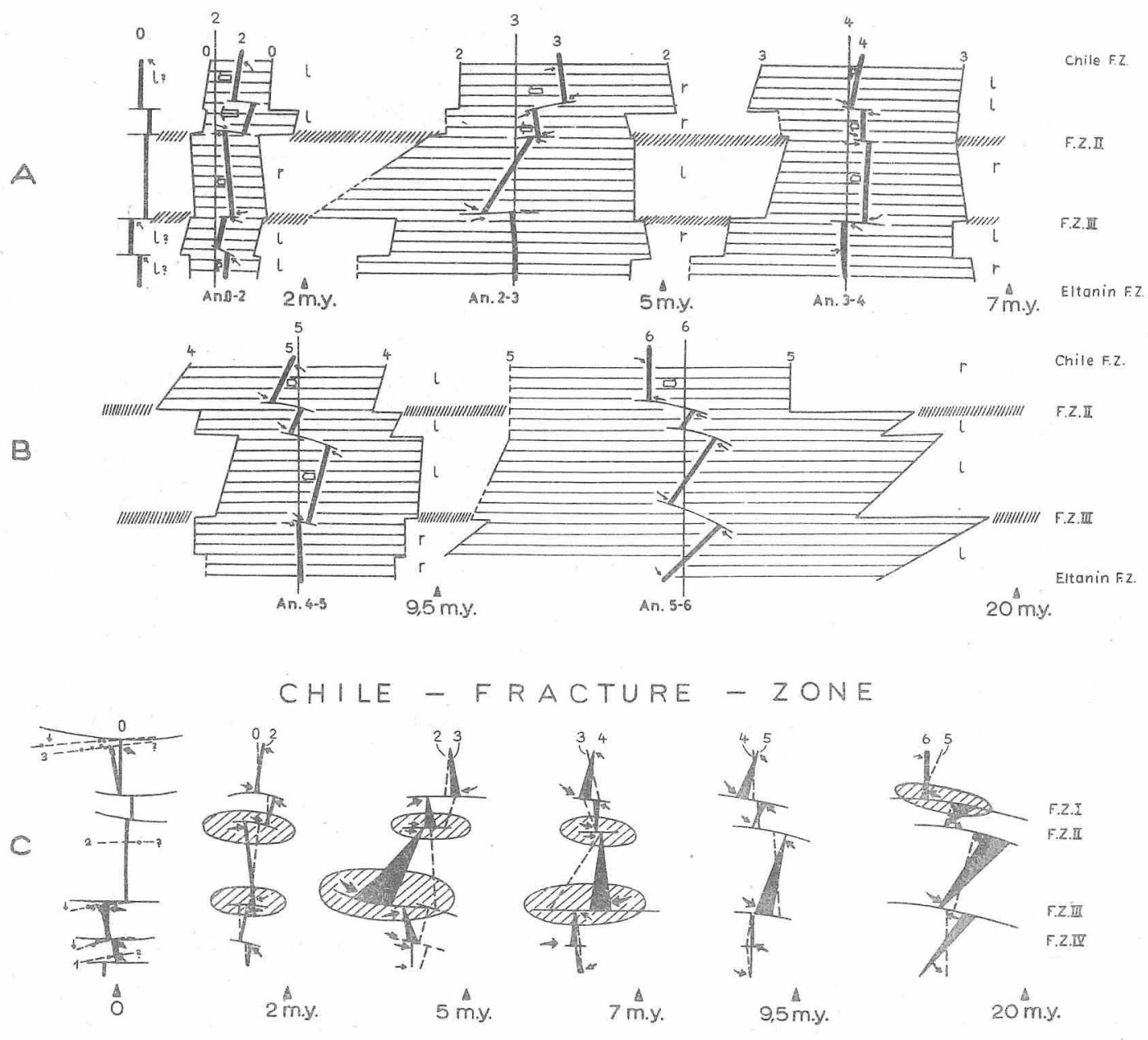

ELTANIN - FRACTURE - ZONE

Fig. 10. Location and anomalies as in Fig.9. A and B - faults with the function of hinge lines: obliquely hatched; thick verticol lines: direction of the rift at the inftiction of the creation of onomalies; fine vertical lines: direction of the game rift at the finel stage of creation of anomalies; small. arrows: rotation sense; $x, 1$ : clockwise or counterclockwise rotation, resp.; thick arrowg: latergl xift shifting. $C$ - base of wedges: intenglified intrusion activity along the rift; top of wedges: average rift activity: dashed lines: reorientated rift position: arrows: rift rotation; hatched areas: faults with temporaxy hinge line function. Column $0 \mathrm{~m}_{\circ} \mathrm{y}_{0}$ - points: earthquakes (GIERLOFF-EMDEIN 1970); dashed rift: preaumed recent rift rotation: dashed fracture zones: presumed postions in the future: points 1 - 3: presumed aditional faults, eventually initial stages. Nurnerals above all colums: numbers of anoralies. 
A counterclockwise rotation of the rift with a aimultaneous weatward shift for $15 \mathrm{~m} \cdot \mathrm{y}$. still continued in the central section for $3 \mathrm{~m} \cdot \mathrm{y} \cdot$, up to $2 \mathrm{~m} \cdot \mathrm{y} \cdot \mathrm{b} \cdot \mathrm{p}$. ; it covered, however, the northern section south of the Chile F.z. $9.5 \mathrm{~m} . \mathrm{y}$. later. Moreover, at that time this section still moved eastward, and showed, therefore, a certain independence. Afterwards, the rift parts were covered by a clockwise rotation 5 to $2 \mathrm{~m} \cdot \mathrm{y} \cdot \mathrm{b} \cdot \mathrm{p}$. , except for the central section, which again passed to a counterclockwise rotation already $2 \mathrm{~m} . \mathrm{y}$. earlier $(7 \mathrm{~m} \cdot \mathrm{y}$. ago, anomaly 3). Thus this rift section showa a special behaviour, rotating since $7 \mathrm{~m}, \mathrm{y} \cdot \mathrm{b} \cdot \mathrm{p}$. in a direction opposite to that of the N. . Pacific Iift. This was left unchanged also during the lagt $2 \mathrm{~m} . \mathrm{y}$. The whole rift between $30^{\circ}$ and $65^{\circ}$ S. was covered by a new counterclockwise rotation, whereas the central section rotated in a clockwise direction, which means that since $7 \mathrm{~m} . \mathrm{y}$. the whole rift has moved at the faults II and III just as on hinges, as is shown by Fig. 8 for the NoE. Pacific Rift at the Mendocino-Pioneer zone, or at the Molokai F.Z., performing pendulum movements that might be designated as a roll of the position of the rift. By this roll the rift is obviously stabilized.

In general, the Pacific-Antarctic Rift has thus been subjected to a counterclock wise rotation for $20 \mathrm{~m} . \mathrm{y}_{\text {. }}$, with the exception of the $3 \mathrm{~m} . \mathrm{y}$. from 5 to $2 \mathrm{~m} . \mathrm{y}_{\circ} \mathrm{b} . \mathrm{p} . \mathrm{s}$ and is in contrast to the clockwise rotation of the rift in the N.E. Pacific $21 \mathrm{~m} . \mathrm{y}, \mathrm{b} . \mathrm{p}$. till today.

\subsection{Recent tendencies}

We suppose that, at recent times, this counterclockwise rotation is still active, and will continue also in the future, as may be concluded from a distribution of recent earthquakes occurring at this rift, almost all of which lie west of the rift sections and in a particular abundance south of the fracture zones. This may point at a future shift of the fracture zones in a southern direction (striking S.S.W.), which has already begun. In three cases additional fracture zones may exist, or may be formed (points 1 to 3; Fig. 10, row C). At the same time, it may be supposed that.five earthquakes west of the rift will effectuate another shift of its parta by rotation. Such considerations may result in the prediction of a general tendency of the occur-

rence of earthquakes at the rifts and fracture zones respectively, on the prerequisite, however, that epicentres are exactly determined. 


\section{Magmatic activity of the rift}

A great deal of ocean tectonics must directly be attributed to the magmatic activity of the rift. The width and shape of anomalies as well as the activity of faults, inter alia, vary as dependent on the spreading rate. This, conversely, permits to draw conclusions on the activity of the rift in geological time.

From detailed studies of the individual anomalies in the N.E. Pacific north of $38^{\circ} \mathrm{N}$. and at the Pacific-Antarctic Rift between the Chile and Eltanin F.Z. 1 it results that the widths of anomalies with different ages vary just as the widths of those originated synchronously at different places. Such variations, already at a distance exceeding $10 \mathrm{~km}$, can also be recognized at the Reykjanes Ridge (58 to $62^{\circ} \mathrm{N}, 24^{\circ}$ to $33^{\circ} \mathrm{W}$ : $\left.\mathrm{Fig} .16\right)$, in the area around the Juan de Fuca Rift and south of the Aleutian Trench between $170^{\circ}$ and $180^{\circ} \mathrm{W}$.

\subsection{Characteristics of rift activity}

(1) The magmatic activity pulsates (a) at the same time at different places of the rift, or of a rift section, which means that more than an average quantity of magma intrudes there; (b) in consecutive intervals at one and the same place of the rift, times of a particularly intense intrusion activity are alternating with those of particularly weak ones.

(2) Pulsating manifests itself in macrorhythme and microrhythms with an average dura-

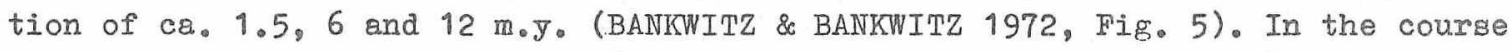
of time centres of magmatic activity having a superordinate significance will shift; at the N.E. Pacific Rift, for example, they did so from north to south 80 to $60 \mathrm{~m} \cdot \mathrm{y} \cdot \mathrm{b} . \mathrm{p}$. f from south to north 60 to $20 \mathrm{~m} \cdot \mathrm{y} \cdot \mathrm{b} \cdot \mathrm{p}$. (Section 2.4.).

(3) Areas showing an intense intrusive activity often occur at the end of a rift section, (i.e., bordering a fracture zone), where the synchronous anomalies do not run parallel to one another (rather have a trapezoidal form), originated without a rotation of the rift (Fig. 12A). At the S.E. Pacific Rift, 7 to 5 m. y. ago, such a centre was situated north of $50^{\circ} \mathrm{S}$. (recent position). In Figs. 9 and 10 , row A, the central part of the anomalies 3 to 4 has the shape of a trapeze, just like the part between the foults III and IV of the anomalies 2 - 3. The unequal activity at the rift is schematically represented in Fig. 10, row C.

(4) The centres are mostly cut off by faults. As a rule, they do not continue beyond a fracture zone (Figs, 10, 12 B): accordingly, the efficacy of faults is very deep. Examples: (a) There were centres of activity for more than $10 \mathrm{~m} . \mathrm{y}$. in the S.E. Pacific (today) north of $50^{\circ} \mathrm{S}$. each time at the end of three rift sectiong (Fig. 10, from 20 to $9.5 \mathrm{~m} \cdot \mathrm{y}_{\bullet} \mathrm{b} \cdot \mathrm{p}$, between frults I and IV), without continuing beyond the faults; (b) the Reykjanes Ridge at $60^{\circ} \mathrm{N} .8$ to $10 \mathrm{~m} \cdot \mathrm{y}_{\circ} \mathrm{b}_{\circ} \mathrm{p}_{0}$ : one of Its centres north of the fault 9 (Fig. 16, column a).

(5) Centres of additional magmatic activity are preferably developed at intersections between rift zones and fracture zones, or at fault-like points. This caused a fault activity also outside the transform sections, because on both flanks of the fault striper of anomelies with unequal width spread away from the rift, as is exemplified by displacements of the limitations of anomalies 6 to 1 (Fig. 9) during the last $\mathrm{A}_{2} \mathrm{~m} \mathrm{\textrm {y }}$ 。 in the area between the Chile and Eltanin F.Z.s in the S.E. Paci̊dơlẹttp://doi.org/10.2312/ZIPE.1978.046 
(6) From (5) It follows that a stepwise shift of the fault flanks is posaible even outalde the tranaform sections (a left-handed diaplacement alternating with a right-handed one). Thus the displacementg originating can almost, or totally, be eliminated in the following time, a movement, however, almost continuously takIng ploce st the fouIte (BANKWITZ \& BANKWITZ 1972, Figs. 2 and 3 ).

(7) If such an additional production extincta, the rift section (a) ney uniformiy continue its magmatic production in its whole length, or (b) at this place may produce less than at the remaining rift. The latter is the rule. - Example: anomaly map of the Reyicjanes Ridge at $60^{\circ} \mathrm{N}$. and of the Juan de Fuca Ridge, 0.8. anomaly 4 west of the mouth of the Columbia River. This is recognized by interlocking stripes magnetlaed nomally and revergely (there is an extension in addition to a constriction, cf. Fig. $12 \mathrm{C})$.

(8) This behsviour also spplies to whole rift parts where the spreading was occasion ally paster then in other rift sections. The greater a maximum of intmalon, the smaller is the minimum following chronologically. - Examplea: (a) Reykjanes Ridge 8 to $10 \mathrm{~m}, \mathrm{y}, \mathrm{b}, \mathrm{p}$. between faults 3 and 4,9 and 10 ; the areas between the faults $1-2,12-12$ and 16 - 17 are more compensated ones (Fig. 16, colum a): (b) the central section between the Chile and Bltanin F.z.s 2 to $4.5 \mathrm{~m}, \mathrm{y} . \mathrm{b} . \mathrm{p}$. (Fig. 9, enomaliea $3-4$, rowg $A$ and B), clearly above all west of the rift: (c) the

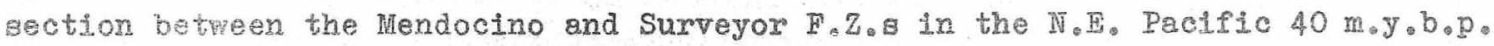
(cf. Fig. 1, BANKWITZ \& BANKWITZ 1972).

(9) There is available, obviously for a long time, a congtant mean amount of magma over a large length of the rift, which, by a self-regulating principle, intrudes cocasionally and locally at the rift in an irregular way. If more than the mean quantity intmode, the fntrusion in the same area is reduced in the following thme interval or in the edjoining area, respectively. This compensating rhythm of 1 to $6 \mathrm{~m} . \mathrm{y}_{\text {. }}$ is supertmposed by macrorhythms and by increased spresding towards the equator.

(10) Tf the intrusions mainly took place on on side of the older main intrugion zone (Kig. $12 \mathrm{D})$, the rift is shifted laterally. - Eramples: Pacific-Antaretic Rift between Chile and Eltanin F.Z.* (Fig. 10, rows A and B). Thick arrows indicate the supposed ahifting, which must have happened up to the thin vertical ine each time in the midst of the blocks. This auxiliery line indieates the limitation of the anomaly toweras the rift.

(11) Rotationg of the rift took place if the magmatic bodies only intruded partially or only at a point on one of its sides. The anomalies then run parallel on both sides of $t$ rift, but in an oblique direction in comparison to the preceding anomaly (Fig. $12 \mathrm{E}$ ). An intrusive zone obviously never ahifts unilaterally. The orientation of the intrusions preaumably shifts only pertially and, in most ca aes, probably only at one end of the rift section. The bagic ider of the diago nel intmision by VOGT et al. (1969) proves, however, to be suitable for \& reconstruction of processes of rotation (Fig. 14, row B). - Example: rift between the Chile and Eltanin F.Z.G (Fig. 10). Small arrowis indicate the presumable direction of rotation partly opposite at the individual rift sectiong (cf. Chapter 4). 


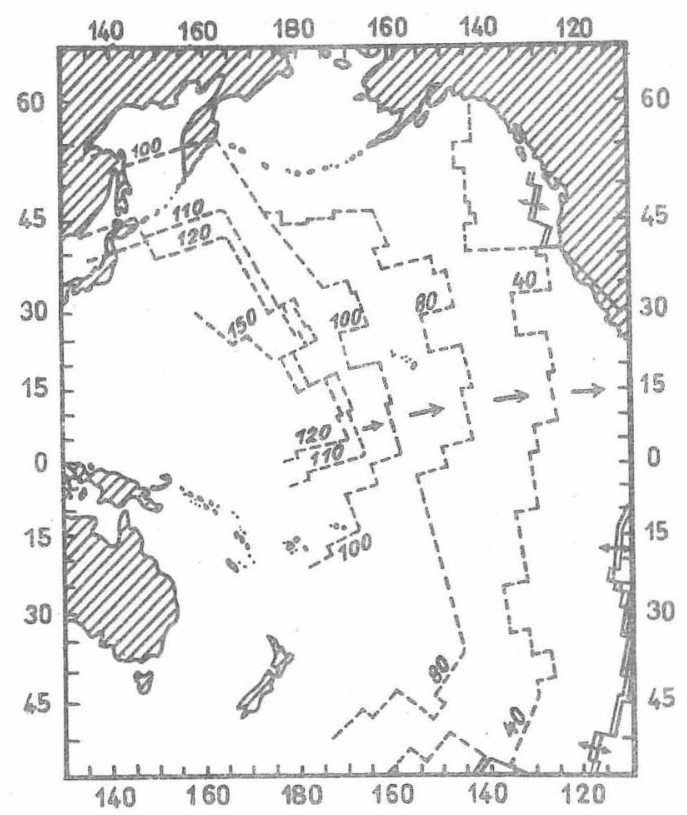

Fig. 11. Lateral rift shlfting towards the east from $150 \mathrm{~m} \cdot \mathrm{y}$ 。 until today (IARSONT \& CHASE 1972)
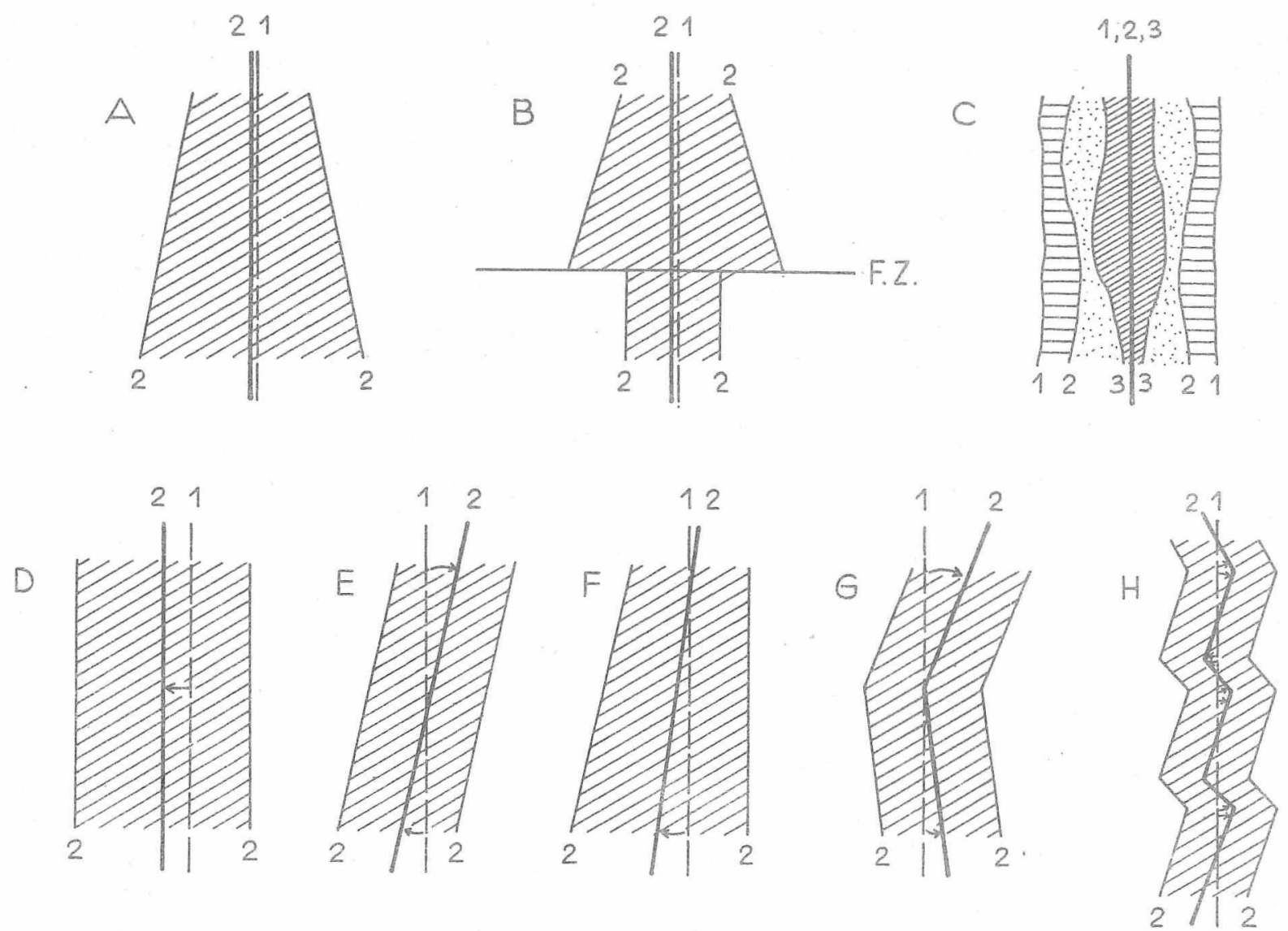

Fifg. 12. Scheme of the presumed magmatic activity of the rift. Hatched: newly created ocean floor. A $-C$ - unequal magmatic activity without rift rotation: D - H - intensified at one side of the former main injection zone; $E$ - $H$ - connected with rotation; $G$ - H connected with creation of hinge points; G without shifting of the kink point: If connected with shifting of the kink 
(12) Kinks of the rift observable in the following time as anomaly kinks (Fig. $12 \mathrm{G}$ ) were formed if places with intrusions shifted unilaterally are not situated close to fracture zones. If such a spot with a tendency towards an injection zone shifting unilaterally was maintained at the rift for a long time ( $5 \mathrm{~m}, \mathrm{y}$. and longer), kinks axranged laterally originate, which are connected by nodal lines. - Examples: in the Gulf of Alagka the rift between the Aja and Sila F.Z.s (Figg.6, 13 and 14). Particularly numerous narrow kinks are shown by the Reykjanes Ridge at (today) $60^{\circ} \mathrm{N}$. , the Kula and East Pacific Rifts at (today) $59^{\circ} \mathrm{N}$ a and $170^{\circ}$ to $180^{\circ}$ W., as well as the Rivera Rift south of Baja California. They also occur at the Juan de Fuca Rift, however, with minor angles. One of the two sections forming a kink is often longer than the other (Fig. $12 \mathrm{H}$ ). At the Reykjanea Ridge (Fig. 16) the kink distances are 10 to 25 up to $50 \mathrm{~km}$.

(13) The different consequences of the rift activity may simultaneously occur in a coribined way at the same point, or part of the rift, such as drift, rotation, or kinking of the rift. Frample: the PacificaAntarctic Rift between the Chile and Eltanin F。Z.s (Fig. 10; cf. Chapter 4)。

\subsection{Hinge zones of the rift rotations}

Hinge zones 8.1 , were already mentioned in the sections dealing with the total rotation of the N.E. Pacific Rift and with the rotations of the Pacificantarctic Rift. In these cases hinge zones are faults where the rift is displaced considerably. This may suggest that an increased activity causing eastward rift shiftings (expressed in kink dislocations towards the east) may take place as a result of increaved mobilization in the upper mantle in definite distances, not only at the intersection points of the rift and fracture zones, but also within these zones themselves. This increased intrusive activity giving rise to shiftings of the rift towards the east is in good accordance with its shift generally supposed towards this direction. Times in which the kink of the rift relatively shifts westward (Fig. 8) would then be regarded as times in which the magmatic activity of the hinge zones has become extinct.

From the simplified representation of Fig. 8 three intervals of activity and three of quiescence are obtained for the Mendocino-Pioneer zone:

\begin{tabular}{cllc}
\hline $\begin{array}{c}\text { Duration } \\
{[\text { m.y.] }}\end{array}$ & \multicolumn{2}{c}{ [m.J.b.D.] } & Anornalies \\
\hline 15 & quiescence & $80-65$ & $32-26$ \\
5 & activity & $65-60$ & $26-24$ \\
20 & quiescence & $60-40$ & $24-15$ \\
8 & activity & $40-32$ & $15-10$ \\
16 & quiescence & $32-? 16$ & $10-5 C$ \\
6.5 & activity & $? 16-9.5$ & $5 \mathrm{C}-5$
\end{tabular}

Thus the quiet intervals durations 15 to $20 \mathrm{~m} \bullet \mathrm{y}$. are twice to three times as long as the activity intervals durations ( 5 to $8 \mathrm{~m}_{0} \mathrm{y}_{0}$ )。 

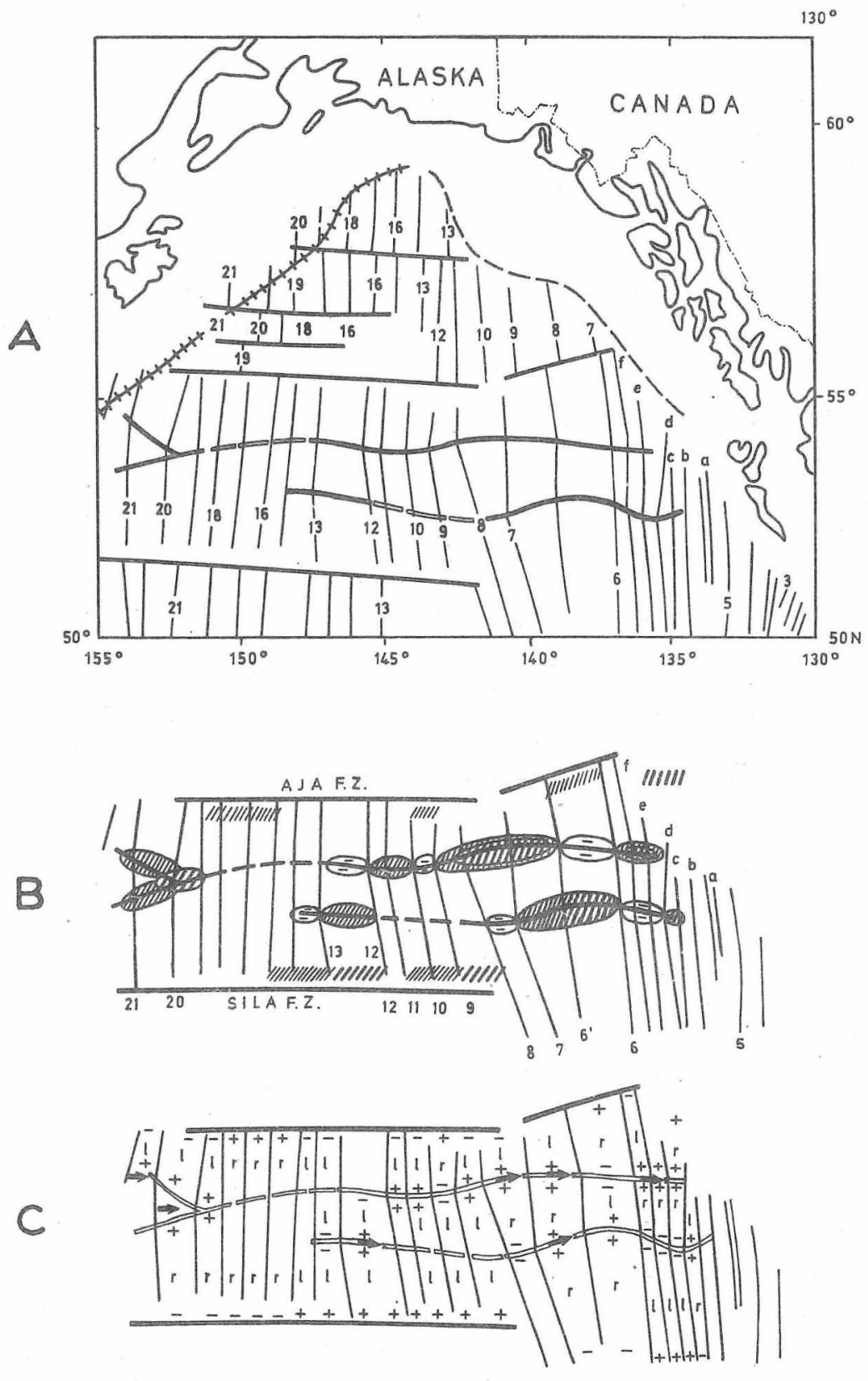

Fig. 13. Hinge lines in the Gulf of Alaska between Aja and Sila F.Z.8. $\Lambda$ - configuration of anomalies and positions of kink points (INAUGIIR \& WAGEMAIT 1973) and both hinge lines; $B$ - hatched areas: intensified intrusion activity, minus: reduced activity on the west liank of the rift; the maximum activity changes from the southern to the northern hinge and vice versa, exept the time of anomaly $7-61 ; C-r$, 1 : clockwise or counterclockwise rotation, resp.; ,$+-:$ intensified or reduced intrusion activity, resp., on the west side of the rift; arrows: shifting of kink points 
PIaces at the rift having a faut-like character often reacted as hinge zones, without being realized a faults. At these points the rift is not displaced, but is only kinked. This statement may be relied on for the area south of the Aleutian Trench from $163^{\circ}$ to $180^{\circ} \mathrm{W}$. (distance of track Iines of magnetic data interpreted by GRIM \& ERIK= SON 1969: $18 \mathrm{~km}$ ); this atatement may also hold true for other areas with a similarly low ditance of track lines.

The magmatic activity of guch a hinge point represents the anomalies of the rift section between the Sila and Aja. F.Z.s in the area between $52^{\circ}$ and $56^{\circ} \mathbb{N}$. in the N. $\mathbb{E}_{0}$ Pacific. Fig. 13 shows the cheracters of this hinge zone, viz.:

(1) All kinks are situeted almost on the same geographical latitude, originated at one point at the rift, and can be connected by nodal lines approximately rumaing paraliel with the frecture zones.

(2) This rift aection between fracture zonea has two binge points roughly dividing it into three parti. They became active 40 and 38 up to $20=10 \mathrm{~m} . \mathrm{y} \cdot \mathrm{b} . \mathrm{p}$. The northerm hinge point has obviously existed already $53 \mathrm{m.y}$. ago and was inactive from 47 to $38 \mathrm{~m} \cdot \mathrm{y} \cdot \mathrm{b} \cdot \mathrm{p}$. The southem hinge point, too, occasionally was inactive.

\begin{tabular}{|c|c|c|c|}
\hline $\begin{array}{c}\text { Duration } \\
{\left[\mathrm{m} \cdot \mathrm{yed}^{-1}\right.}\end{array}$ & \multicolumn{2}{|c|}{$\begin{array}{l}\text { Time } \\
{[\mathrm{m} \cdot \mathrm{y} \cdot \mathrm{b} . \mathrm{p} \cdot]}\end{array}$} & \multirow[t]{2}{*}{ Anomalies } \\
\hline (a) North & ern hinge zo & & \\
\hline 6 & activity & $53-47$ & $21-19$ \\
\hline 9 & quiescence & $47=38$ & $19-13$ \\
\hline $18-28$ & activity & $38-20(10)$ & $13-6(5)$ \\
\hline \multicolumn{4}{|c|}{ (b) Southern hinge zone } \\
\hline 4 & activity & $39-35$ & $14=12$ \\
\hline 6 & quiescence & $35-29$ & $12=8$ \\
\hline $9-19$ & activity & $29-20(10)$ & $8-5(6)$ \\
\hline
\end{tabular}

(3) The nodel lines and hinge zones, respectively, are curved arch-like on account of a temporaxy, small shift of the kink towards the south and north, respectively. Provided the se shiftings are real ones, the $\mathbb{N}_{0}-S_{\text {s }}$ shifts are due to the respective rotation conrected with the E.-W. shift of a kink. The kink is the result of a rotetion of one of the two adjacent rift parts, with the kink point shifting towards the north, or south, ss dependent on the circular arc. It ofter occurg that an adjacent rift part only rotates, or one part rotates more than another, with the curvature produced by the more intense rotation (Figs. 6 and 13).

(4) By means of these hinge points the rift rotated stepwige. It was readjusted to a new position of the pole by way of amall steps, which may be equal in value to the principle of the smallest working effort (VOGT et al. 1969). These steps are repreaented in Fig. 14 for the anomalies 13 - 5 in this area.

(5) The magmatic production may obviously become more asymmetric at a hinge than in other places of the rift (cf. Figs, $12 \mathrm{~F}$ and 14, rows $\mathrm{A}$ and $\mathrm{B}$ ), that is, on one side preponderently, however, north and south of the nodal point. At a fault in trusions are mostly unilateral at one flank only. If $E$ ) at both flanks, the fault also reacts like a hinge. 
A

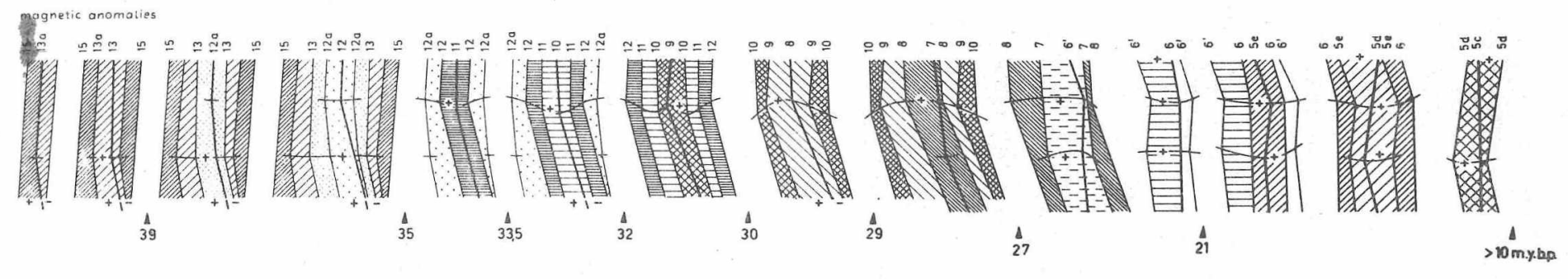

$\mathrm{B}$
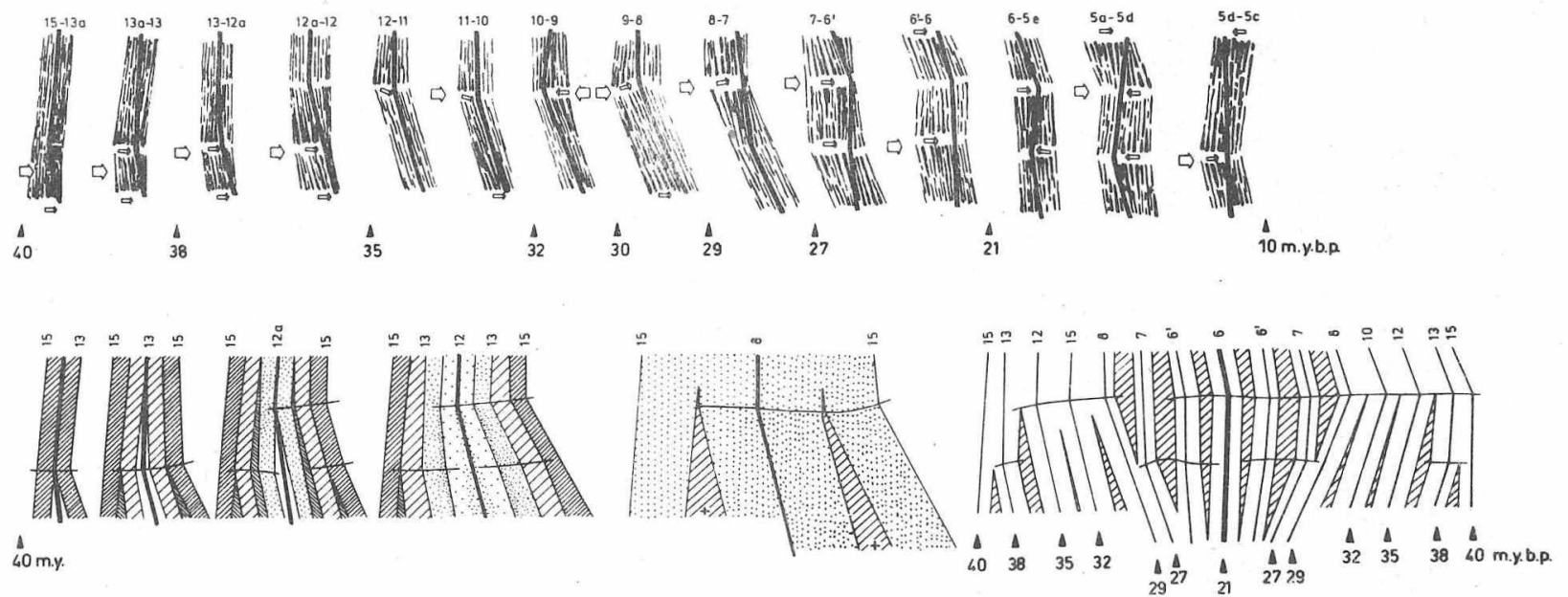

Fig. 14. Iocation and configuration of anomalies as in Fig. 13. A - step-by-step rotation of single parts of this rift section which is to be supposed on the strength of the kinks, provided an equal magmatic activity along the whole rift section, but unequal distribution of the intrusions at one side of the rift (+). $B$ - onesided main intrusion zone causes the change of rift position or of the kink, resp. (arrows). C - rift rotation on the understanding of an unequal magmatic activity along the rift section. Hatched areas: intensified intrusion. Only if the anomalies at both aides of the rift are preserved, it may be determined which case (A or C) is present. 
(6) The kink is either fired at the hinge and rotates at the free ends (Frig. 14: anomalies 15 to 12; another place of the rift has a major magmatic activity), or is shifted in the hinge area due to a particularly intenge activity (anomalies 12 to 7: Fig. 14, rows $A$ and $B$ ). In Fig. 13 B the first case is characterized by a minus algn and the second case by a plus sign.

(7) The nodal point shifts together with the rift (Figg. 13 and 14).

(8) The nodal point couples the two rift parts, compels them to react in common, or prevents a fault displacement.

(9) Kinks may occur at narrow distances, auch as at the Reykjanes Ridge (Fig. 16), Gorda Ridge, Pacific and Kula Ridges (anomalieg 29 to 25). They shorten the rift in itr longltudinal direction.

Differences of the rete of apreading are transferred from the rift aections into the platea as unequal displacements of faults. Fither the onergy will be absorbed by deformation or transmitted through the whole plate. The latter case seems improbable, because It car be realized only when the plates are divided into independent atrips. But the point-Iike centres of ectivity must cause defornations in the older intrusions. According to our opinion, tectonically deformed basalts may occur especielly in the hinge zones of rifts as they were described above. 


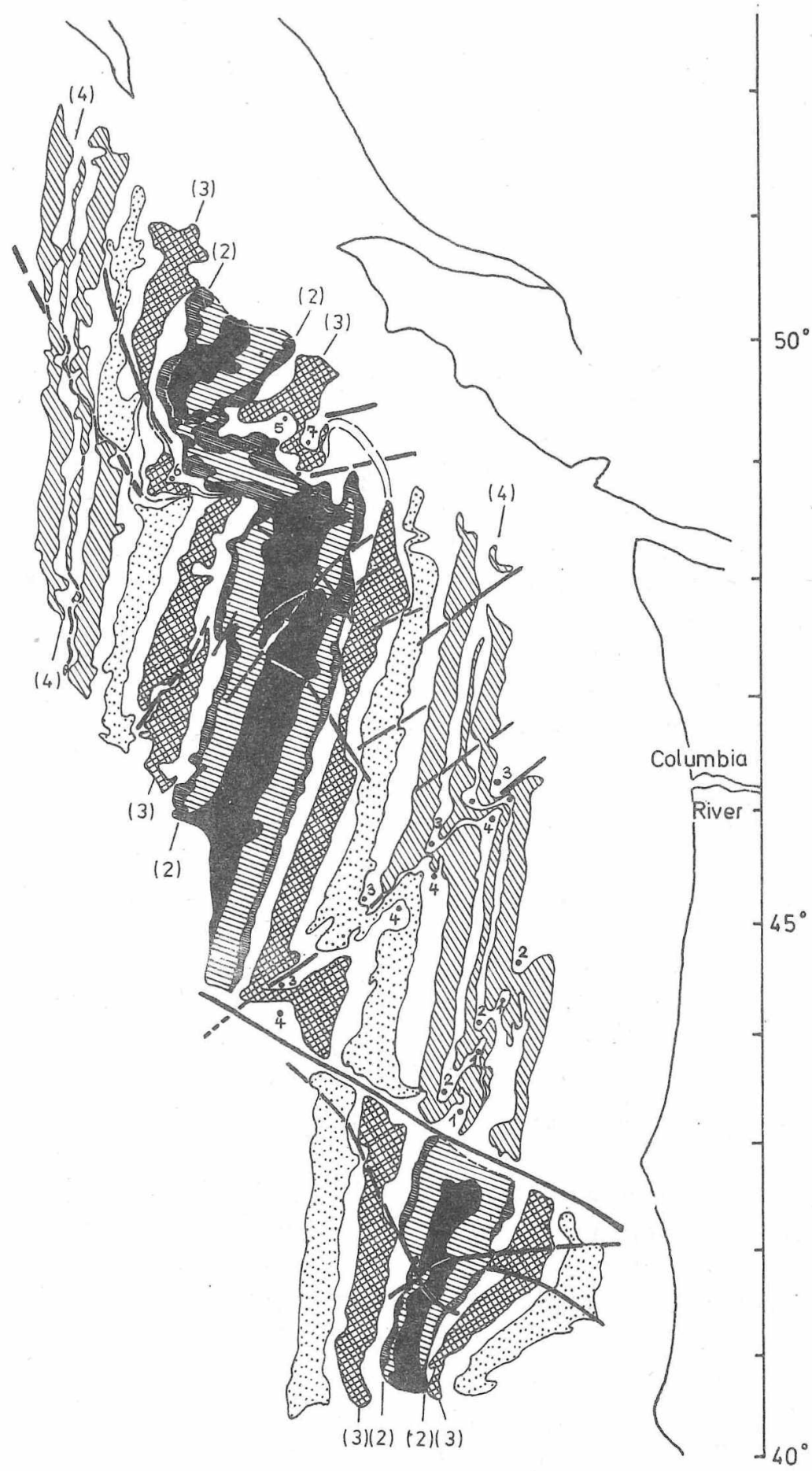

Fig. 15. Deformation of the Juan de Fuca and Gorda Rifts between $40^{\circ}$ and $50^{\circ} \mathrm{N}$. Paultfolding and fault displacements. Black: rift area; numerals in brackets: numbers of anomalies. Source for the configuration of anomalies: RAFF \& MASON 1961. Fold-like bending of the rift at $49^{\circ} \mathrm{N}$. and of the anomalies 3 and 4 between $44^{\circ}$ and $46^{\circ} \mathrm{N}$. Points $1-7$ : bendings. Right-hand side of the rift: compression connected with rift rotation; left-hand side: dominating extension 
6. Plate deformation

Out of the various signs indicating a deformation of plates with an oceanic crust two phenomena only will be digcussed here.

\subsection{Rift rotation at a collision of plates}

The Faralion Plate in the N.E. Pacific may be widely abduced, the gmall remaina only know being the Juan de Fuca Plate and the Rivera Plate. There some extremely intense rift rotations seem to be traceable to a collision between the Pacific and the American Plates. According to our opinion, the remaining residual sections of the two rifts were influenced and carried along during the collision by the south-west movement of the Amexican Plate. This is valid already for the southerm part of the Farelion Plate, when the East Pacific Rift got into the immediate proximity of the American Plate: The rift, $32 \mathrm{~m} \cdot \mathrm{y}$, ago, by $15^{\circ}$ and $30^{\circ} \mathrm{N}$, reapectively, jumped towards

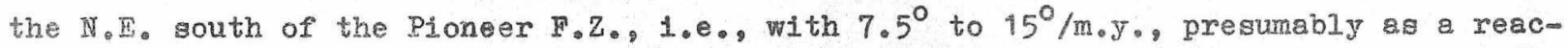
tion upon the southward drifting American Plate. There is, in our opinion, a deformation of the oceanic plate in the time before, or during, the subduction. In the following $3 \mathrm{m.y}$. the rift was able to "reorganize" itself once more, that is to say, from 30 to $27 \mathrm{~m}, \mathrm{~J} \cdot \mathrm{b} . \mathrm{p}$. this rotation partially was eliminated by $6^{\circ}$, but from 27 to $21 \mathrm{~m} . \mathrm{y} \cdot$ b.p. this rift already rotated by $15^{\circ}$ towards the north-east. This anomaly is the last that has been preserved.

The Intense counterclockwise rotation of the anomalies 6 - 5, west of Baja Califormia, is a result of the plate collision, just ss the extrerne clockwise rotation by $13^{\circ}$ to $40^{\circ}$ in $11.5 \mathrm{~m} . \mathrm{y}$. continuing from anomaly 5 till present time. The amount of rotation 8lwayg increases from south to north (Rivera $14^{\circ}$, Gorda $18^{\circ}$, Juan de Fuca Rift $20^{\circ}$ to $40^{\circ}$; cr. Fig. 15). The asymmetric position of anomaly 3 at the Rivera Rift is due to a distinct decrease of the intrusive activity at the rift from $S . W$. to N.E.

\subsection{Rift shortening due to compression}

A primarily active internal deformation of the plates and rifts can be observed in addition to this secondary, passive rotation of the rift and Farallon Plate during the collision. Owing to the intense compression to be ascribed to the Pacific and American Plates moving towards each other, the rift system was compressed and shortened together with the adjacent anomalies, so that a large-area fault-folding took place. We distinguish several phases:

(a) Rift shortening dus to manifold kinking. This is the present-day stage of the Rivera Rift, and is also shown by the Reykjanes Ridge at $60^{\circ} \mathrm{N}$, s. Ithough developed to a minor degree (cf. Fig. 16). It is the type of a compression continuous$1 \mathrm{y}$ increasing slowly.

(b) Shortening due to some few large kinks laterally evading in fold-like bends and forming a fault-folding (cr. Fig. 15 after Fig. 1 in RAFF \& MASON 1961, and Fig. 4 in VINE 1968). It is due to an intense constriction rapidly increasing. In this area the folding may only have begun more than $2 \mathrm{~m} \cdot \mathrm{y} \cdot \mathrm{b}_{\circ} \mathrm{p}_{\circ}$ because the stripes magnetized normally $\left(3.5\right.$ to $\left.2.5 \mathrm{~m}, \mathrm{y} \cdot \mathrm{b}, \mathrm{p}_{0}\right)$ at $45^{\circ} \mathrm{N}$., which originated prior to 

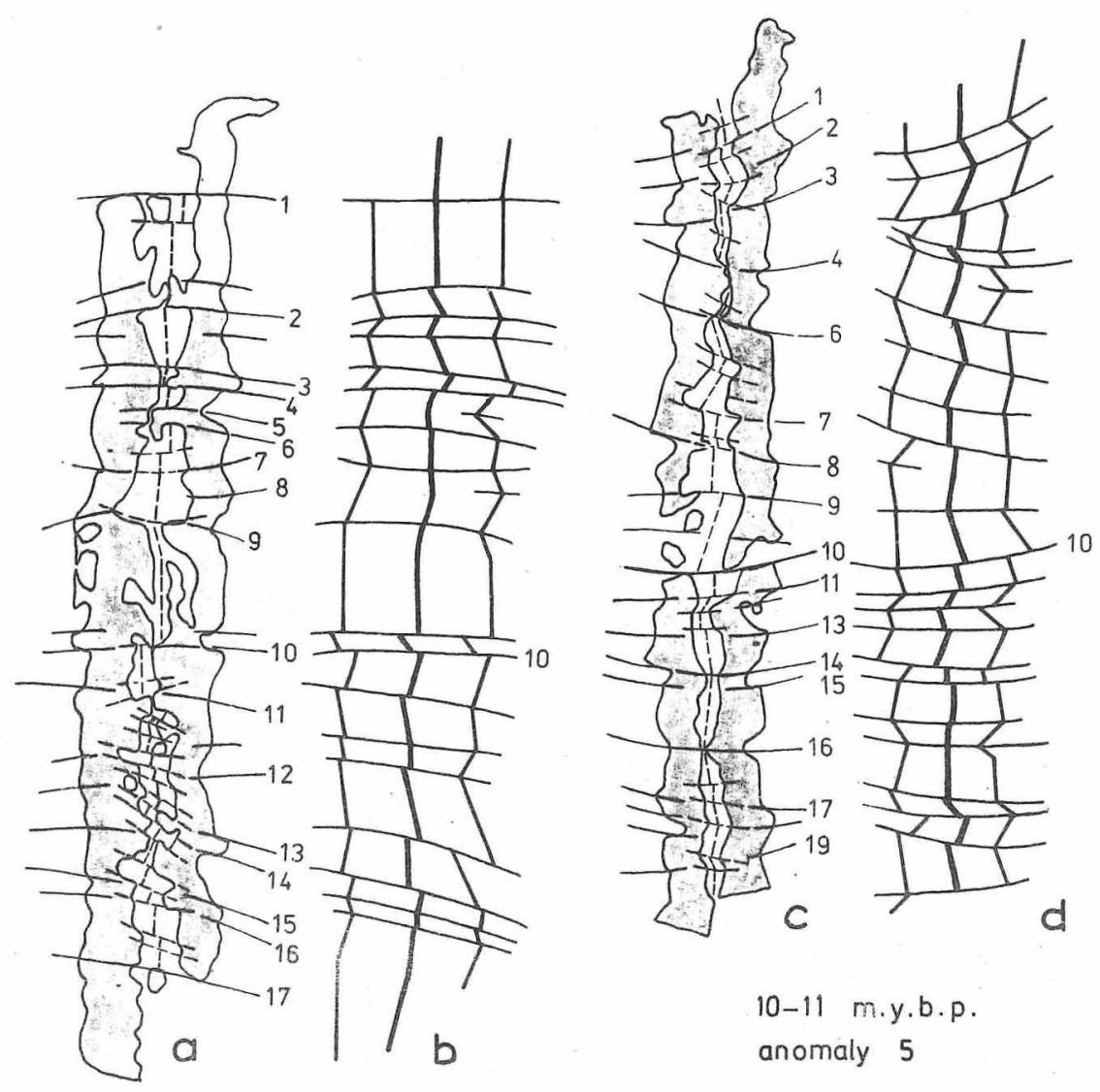

$10-11$ m.y.b.p. anomaly 5

$8-10 m \cdot y \cdot b \cdot p$.

Fig. 16. Reykjanes Ridge at $60^{\circ} \mathrm{N}$. (HEIRTZLER et al. 1966). a and c: the distances between two simultaneous atripes with normal magnetization at both sides of the rift were eliminated. The central areas show the initiation of new stripes with reverse magnetization. Dashed vertical lines: supposed position of the main injection zone before 8 and $10 \mathrm{~m} \cdot \mathrm{y}_{\cdot} \mathrm{b} \cdot \mathrm{p}_{\circ}$; horizontal lines $1-17$ and 1 - 19: minor faults $(e . g, 10)$ or hinge lines active $10 \mathrm{~m}, \mathrm{y}$, (a) and $11 \mathrm{~m} . \mathrm{y}_{\circ}$ (b) ago. 3 and $d:$ shapes of the column $a$ and b representing kinks of the rift during the creation of the atripes of ocean floor 
the anomaly 2, were also folded. At $49^{\circ} \mathrm{N}$. the rift shows a weaker stage of bending (sigmoidal fold), at $45^{\circ} \mathrm{N}$. a more intense one (zigzag fold). In places, a small-dimensioned additional folding must be assumed, as otherwise it is only know from the continentrl crust (points $1-6$ in Fig. 15). With the bending north and south of the Blanco $F . Z$. the northem end of anomaly 3 also points at a preVious fault-folding prior to the shearing and displacement of the bending for more than $100 \mathrm{~km}$. This displacement may have been realized $2.5 \mathrm{~m} . \mathrm{y}$. ago only, 1.e., after formation of the stripe normally magnetized; it may, however, still continue today. This means a horizontal shift by $5 \mathrm{~cm} / \mathrm{y}$. (since the beginning of the Pleistocene). -

The late beginning of the faul-folding at $45^{\circ} \mathrm{N}$. results from the supposition that the rift did no longer produce in such an "overturned" position as it is today (N.W. Iimb). A production in such a position must be demanded if the bending had already taken place 3 or $4 \mathrm{~m} \cdot \mathrm{y} \cdot \mathrm{b} \cdot \mathrm{p}$. At $49^{\circ} \mathrm{N}$. we suppose that in the $E_{0}-W$. bending the anomaly 2 is still completely developed, whereas the anomaly 1 reprem sents the last stripe formed. The recent stripe magnetized normally could not originate, which means that $1 \mathrm{~m}, \mathrm{y}$. ago the fault-folding became so intense that this rift section was no longer productive. This degree of folding aupports the assumption that the fault-folding at $45^{\circ} \mathrm{N}$. only began intensely about $2 \mathrm{~m} \cdot \mathrm{y} \cdot \mathrm{b} \cdot \mathrm{p}$.

(c) Origin of additional fractures and of the clockwise-rotating displacement: Not only the ritt but also the remainder of the Faralion Platte and a atripe about $100 \mathrm{kn}$ wide of the Pacific Plate (north of $48.5^{\circ} \mathrm{N}$ ) were rotated in a clockwise direction, widening the Pacific Plate and compressing (shortening) the Faralion Plate with the rift. West of $47^{\circ} \mathrm{N}$, however, the shortening encroaches as far as the Pacific Plate, with the area north of $48.5^{\circ} \mathrm{N}$. rotating on kinked faults (VINE 1968), or on listric surfaces (described by PAVONI 1966), which represent a later

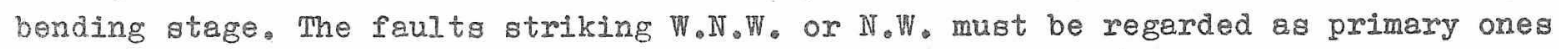
and correspond to the compression rotating clockwise of this area. The faults rumning $N_{0}$. secondarily result from a further compression of the fault-foldings and represent its latest stage. There the folds were sheared and neighbouring anoma lies were also displaced.

By eliminating all bendings and kinks, it is shown (cf. Fig. 17) that the anomaliea 2 and 3, east of the rift of Cape Blanco to the Juan de Fuca Strait, have neer. $1 \mathrm{y}$ the same extengion as the anomaly $4,7 \mathrm{~m} \cdot \mathrm{y} \cdot \mathrm{b}, \mathrm{p}$. Today, at the Juan de Fuca Rift (with the great bending at $49^{\circ} \mathrm{No}$ ), the anomaly 2 is shortened by about $1 / 7$ to 85.3 per cent of the original length, which must widely have taken place during the last $2 \mathrm{~m} \cdot \mathrm{y}$. 


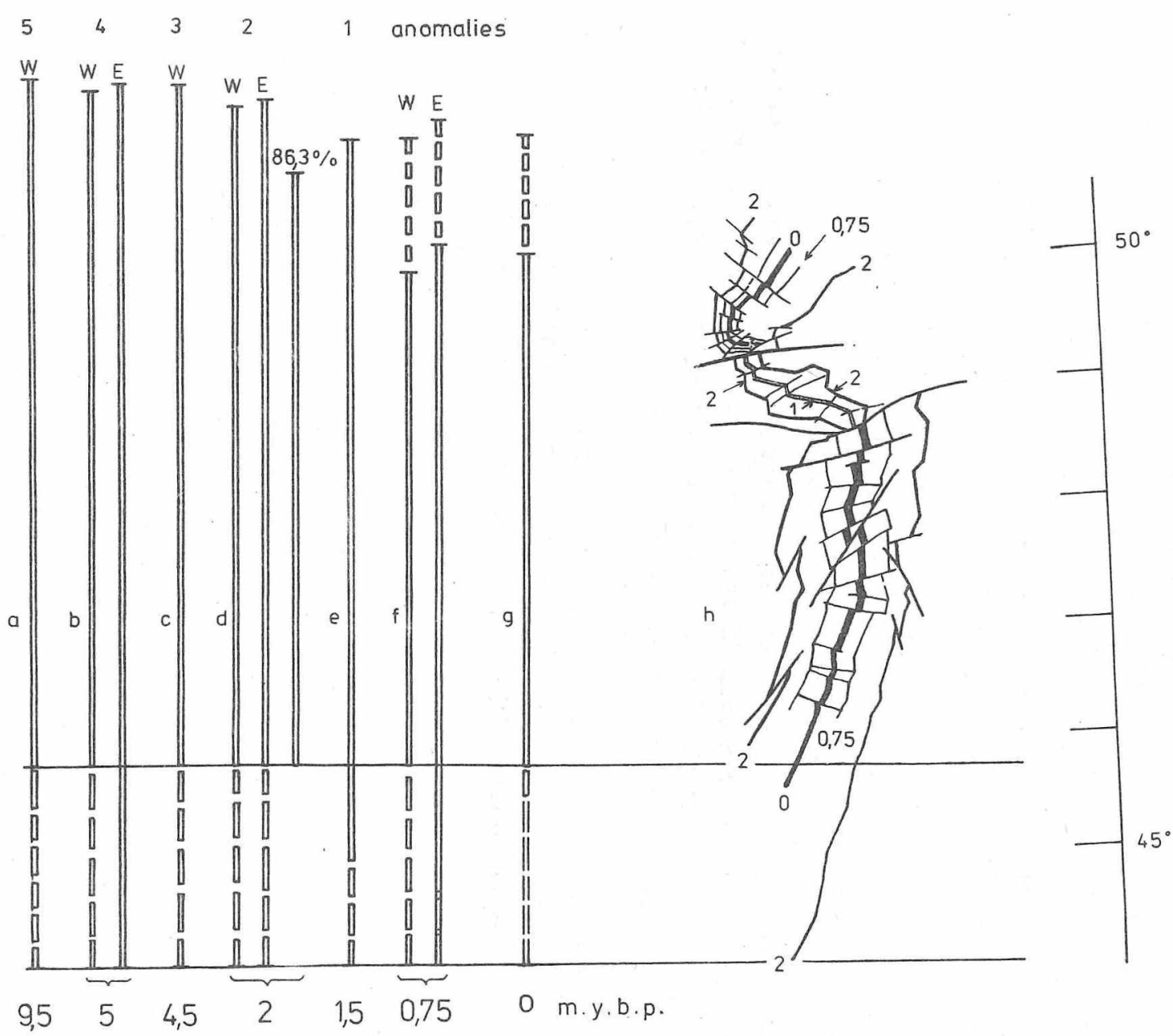

Fig. 17. Juan de Fuca Rift between $45^{\circ}$ and $50^{\circ} \mathrm{N}, a-g-$ elimination of the rift kinks of the anomalies $1-5$ (a - $f: \mathbb{W}-$ west of the rift, $E$ - - east of the rift); $d$ : the most right column is shortened regardless of the minor kinks to $86.3 \%$. $f$ - g: last anomaly with normal magnetization which is missing in the bending at $49^{\circ} \mathrm{N}$. This dead rift section is added in the upper part of $f$ and $g$ (dashed); $f$ : outer contour of the stripe $\mathrm{h}$; $\mathrm{g}$ : recent rift axis; $\mathrm{h}$ : configuration of the Juan de Fuca Rift with anomalies 1 $\left(1.5 \mathrm{~m}_{\bullet} \mathrm{y}_{\bullet}\right)$ and $2\left(2 \mathrm{~m} \bullet \mathrm{y}_{\bullet}\right)$ after RAFF \& MASON 1961; numerals: $\mathrm{m}_{\bullet} \mathrm{J}_{\bullet} \mathrm{b}_{\bullet} \mathrm{p}_{\bullet}$ 


\section{Conclusions}

It should be noted that the rift sections always have migrated to another position since 80 mio years $b . p$. The permanent rotation of the East Pacific Rift (Fig. 2) must be divided into three stages of first-order rotations lasting about 40, 20 and again $20 \mathrm{~m} \cdot \mathrm{J}$. The general clockwise rotation covering the whole rift $\left(35-40^{\circ}\right)$ was inter-

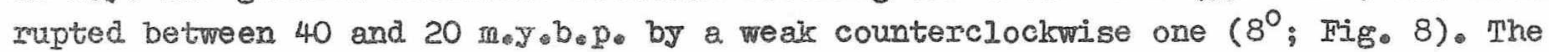
stages are composed of six periods of changing rotations with average durations of $10 \mathrm{~m} \cdot \mathrm{y}$. only. It may be supposed that all these rotations are a readjustement of the rift to a changed position of the spreading pole.

Contrary to these rotations the plate was stabilized by short-time oscillatory rotations representing compensating movements of the rift. They may concern the whole rifft, or may be limited regionelly.

There exists a comnection between hinge zones and faults, resp., and such pendulum movements. Hinge zones are zones of weakness of the rift (Hig. 13), which can become fault zones. They may be observed at the $\mathbb{N}_{0} \mathbb{E}_{\odot}$ and $\mathrm{S}_{\odot} \mathrm{E}_{\odot}$ Pacific Rifts as well as the North Atlantic Rift. Up to now they were not mentioned in literature.

The internas deformation of oceanic plates is demonstrated by the Pacific and Juan de Fuca Plates off Califormia representing kinks of rift, fautefolding and strike slip movements on faults which became intense about $1-2 \mathrm{~m} \cdot \mathrm{J} \cdot \mathrm{b} \cdot \mathrm{p} \cdot$ (Fig. 17). 
References

[1] ATWATER, T.: Implications of the plate tectonics for the Cenozoic tectonic evolution of western North America. Geol. Soc. Amer. Bull., Boulizer 81 (1970) 12, p. 3513-3536

[27 ATWATER, T.; MENARD, H.W.: Magnetic lineations in the northeast Pacific, Earth and planet. Sci. Lett., Amsterdam I (1970) 5, p. 445-450

L37 BANKWITZ, P.; BANKWITZ, E.: Zur tektonischen Bntwicklung des Nordostpazifik. Geologie, Berlin 20 (1972) 4/5, S. 393-408

L47 GIERLOFF-EMDEN, H.G.: Tektonisch-geologische tbersichtskarte der Ozeane der Erde. Dt. hydrogr. Z., Hamburg 23 (1970) 3, S. 118-120

$[5$

GRIM, P.J.: ERICKSON, B.H.: Fracture zones and magnetic anomalies south of the Aleutian Trench. J. geophys. Res., Richmond 74 (1969) 6, p. 1488-1494

HEIRTZLER, J.R。: Sea-Ploor spreading. Sci. Amer., New York 219 (1968) 6, p. 60-70

27 HEIRTZLER, J.R.; LePICHON, $x_{0}:$ BARON, J.G.: Magnetic anomalies over the Reykjanes Ridge. Deep-Sea Res., Oxford 13 (1966) 3, p. 427-444

HERRON, E.M.: Crustal plates and sea floor spreading in the southeastern Pacific。 Antarctic Res. Ser., Washington 15 (1971), p. 229-237

C97 HERRON, E.M.: Sea-floor spreading and the Cenozoic hiatory of the East-Central Pacific. Geol. Soc. Amer. Bull., Boulder 83 (1972) 6, p. 1671-1692

LO) IARSON, R.I.: CHASE, C.G.: Late mesozolc evolution of the western Pacific ocean.

Geol. Soc. Amer. Bull., Boulder 83 (1972) 12, p. 3627-3644

[717

MOINAR, P.; ATWATER, T.; MAMMHRICKX, J•; SMITH, S.M.: Magnetic anomalies, bathymetry and the tectonic evolution of the South Pacific since the late cretaceous. Geophys. J. Res. astr. Soc., Oxford 40 (1975), p. 383-420

NAUGLER, F.P.: WAGEMAN, J.M॰: Gulf of Alaska: Magnetic anomalies, fracture zones, and plate interaction. Geol. Soc. Amer. Bull., Boulder 84 (1973) 5, p. 1575-1584

PAVONI, N.: Tectonic interpretation of the magnetic anomalies southweat of Vancouver Island. Pure and appl. Geophys. 63 (1966) 1, p. 172-178

RAFF, $A_{B} D_{0}:$ MASON, R.G.: Mognetic survey off the west coat of North America, $40^{\circ} \mathrm{N}$. Iatitude to $52^{\circ} \mathrm{N}$. latitude. Geol. Soc. Amer. Bull., Boulder T2 (1961) 8, p. 1267-1270

STOVER, C.W.: Seismicity and tectonics of the east Paciflc Ocean. J. geophys. Res., Richmond 78 (1973) 23, p. 5209-5220

T67 VAIN ANDEL, T.H.: Cenozoic migration of the Pacific Plate, northward ahift of the axis of deposition, and paleobathymetry of the central equatorial Pacific.

Geology, Boulder 2 (1974) 10, p. 507-510

VINE, F.J.: Magnetic anomalies aøsociated with mid-ocean ridges. In: PHINNEY, R.A. (Ed.), The History of the Earth's Crust, p. 73-89. Princeton: Princeton University Press 1968

VOGT, P.R.; et al.: Discontinuities in aea-floor spreading. Tectonophysics, Amsterdam \& (1969) 4-6, p. 285-317

T97 VOGT, P.R.; AVERY, O.E.: Detailed magnetic surveys in the northeast Atlantic and Labrador Sea.

J. geophys. Res., Richmond 79 (1974) 2, p. 363-389 
